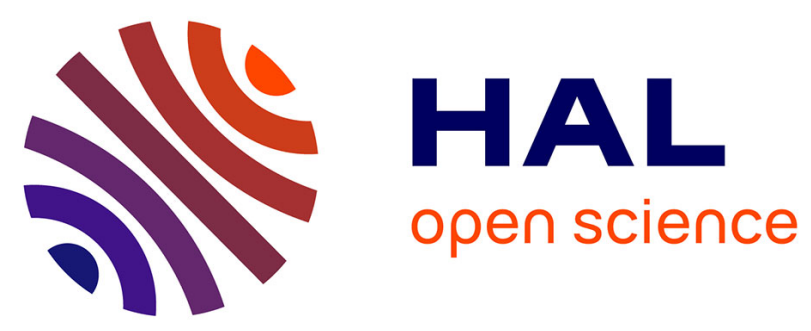

\title{
Exposure to heterocyclic aromatic amines from consumption of cooked red meat and effect on human cancer risk. A review
}

Mayte Sanz Alaejos, Venerando González, Ana M. Afonso

\section{To cite this version:}

Mayte Sanz Alaejos, Venerando González, Ana M. Afonso. Exposure to heterocyclic aromatic amines from consumption of cooked red meat and effect on human cancer risk. A review. Food Additives and Contaminants, 2007, 25 (01), pp.2-24. 10.1080/02652030701474235 . hal-00577471

\author{
HAL Id: hal-00577471 \\ https://hal.science/hal-00577471
}

Submitted on 17 Mar 2011

HAL is a multi-disciplinary open access archive for the deposit and dissemination of scientific research documents, whether they are published or not. The documents may come from teaching and research institutions in France or abroad, or from public or private research centers.
L'archive ouverte pluridisciplinaire HAL, est destinée au dépôt et à la diffusion de documents scientifiques de niveau recherche, publiés ou non, émanant des établissements d'enseignement et de recherche français ou étrangers, des laboratoires publics ou privés. 


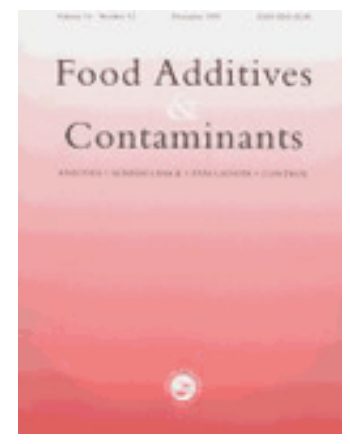

\section{Exposure to heterocyclic aromatic amines from consumption of cooked red meat and effect on human cancer risk. A review}

\begin{tabular}{|r|l|}
\hline Journal: & Food Additives and Contaminants \\
\hline Manuscript ID: & TFAC-2007-098.R1 \\
\hline Manuscript Type: & Review \\
\hline Author: & 21-May-2007 \\
\hline Complete List of Authors: & $\begin{array}{l}\text { Sanz Alaejos, Mayte; University of La Laguna, Analytical Chemistry, } \\
\text { Nutrition and Food Sciences } \\
\text { González, Venerando; University of La Laguna, Analytical } \\
\text { Chemistry, Nutrition and Food Science } \\
\text { Afonso, Ana; University of La Laguna, Analytical Chemistry, } \\
\text { Nutrition and Food Science }\end{array}$ \\
\hline Mdditives/Contaminants: & Hetrocyclic amines \\
\hline Food Types: & Animal products - meat, Fish and fish products, Processed foods \\
\hline &
\end{tabular}

\section{SCHOLARONE ${ }^{m}$ Manuscripts}


Exposure to heterocyclic aromatic amines from consumption of cooked red meat and effect on human cancer risk - a review

Maite Sanz Alaejos, Venerando González and Ana María Afonso

Department of Analytical Chemistry, Nutrition and Food Science.

University of La Laguna. 38205-La Laguna (Santa Cruz de Tenerife), Spain.

e-mail:mtsanz@ull.es 


\begin{abstract}
This review covers the bibliographic data from the last ten years, on the possible carcinogenicity of heterocyclic aromatic amines (HAAs) in humans. Aspects such as red meat intake, cooking methods applied to red meat, and doneness of cooking are discussed from an epidemiological point of view. The role in the HAAs carcinogenicity has been assigned to two main factors, firstly the very high frequency of consumption of red meat, and secondly very darkly browned meats from cooking. However, there are some uncertainties associated with epidemiological results such as the presence of other carcinogens, co-carcinogens and anti-carcinogens in the diet, analytical results on HAAs content in foods, food frequency questionnaires and, mainly, genetic susceptibility to HAAs. It is concluded that there is not sufficient scientific evidence to support the hypothesis that human cancer risk is due specifically to the intake of HAAs in the diet.
\end{abstract}

Key words: Heterocyclic aromatic amines; intake; human cancer risk

Introduction

To date, more than twenty heterocyclic aromatic amines (HAAs) have been isolated as potent mutagens in the Ames/Salmonella test, and have been characterized. Table I shows their structures, chemical and abbreviated names.

Insert Table I about here

These HAAs contain from two to five (generally three) condensed aromatic cycles with one or more nitrogen atoms in their ring system and, usually, one exocyclic amino group. In general, they are formed during heating process of organic products containing nitrogenous compounds, mainly proteins. This formation is mainly temperature-dependent and so HAAs are classified into at least two groups due to the formation process. HAAs formed at temperatures between 100 and 
$300^{\circ} \mathrm{C}$ are known as "thermic HAAs", IQ type or aminoimidazoazarenes. The ones formed at higher temperatures, above $300^{\circ} \mathrm{C}$, are known as "pyrolytic HAAs" or non-IQ type. Thermic HAAs are generated from the reaction of free amino acids, creatin(in)e and hexosas. The precursor undergoes further dehydration and cyclization to form the observed pyrrole and pyridine derivatives. The heterocyclic pyridines and pyrazines formed in the Maillard reaction between hexose and amino acids then undergo further transformation with participation of Strecker aldehydes and creatin(in)e to produce imidazo-quinoxalines, perhaps through free-radical reactions. However, with temperatures about $225-250^{\circ} \mathrm{C}$, these compounds seem to degrade or react with other compounds. On the other hand, the formation takes place through pyrolytic reactions between amino acids and proteins in the case of the non-IQ type. Pyrolysis occurs at temperatures well above $300^{\circ} \mathrm{C}$, and produces many reactive fragments through radical reactions. These fragments are believed to condense to form new heterocyclic structures, and pyrolytic mutagens might be formed via freeradical reactions.

HAAs are mutagenic not only for bacteria, but also for some mammalian cell systems and can produce chromosomal aberrations and sister chromatid exchanges in cultured cells. Some of them show higher mutagenic activity in bacteria and certain animals than typical mutagens/carcinogens such as benzo\{a\}pyrene or aflatoxin $B_{1}$. HAAs like harman and norharman are not mutagenic, but enhance the genotoxicity of mutagenic HAAs. In 1993, the International Agency for Research on Cancer (IARC, 1993) considered eight of the HAAs tested (MeIQ, MeIQx, PhIP, A $\alpha \mathrm{C}, \mathrm{MeA} \alpha \mathrm{C}$, Trp-P-1, Trp-P-2 and Glu-P-1) as possible human carcinogens (class $2 \mathrm{~B}$ ) and one (IQ) as a probable human carcinogen (class 2A). More recently, in 2002, IQ was included as reasonably anticipated to be a human carcinogen in the NTP $10^{\text {th }}$ Report on Carcinogens (NTP 2002). Latterly, MeIQ, MelQx, and PhIP are also listed in the NTP $11^{\text {th }}$ Report on Carcinogens (NTP 2004) as reasonably anticipated to be human carcinogens, together with IQ. These results are based on the sufficient evidence of carcinogenicity and supporting genotoxicity data obtained in long-term animal feeding studies. Although epidemiological evidence suggests that consumption of well-done or grilled meat may be associated with increased cancer risk in humans, the data are 
insufficient to support the conclusion that this risk is due specifically to MelQ, MelQx, or to PhIP, present in these foods. Case-control studies show very conflicting results. Other case-control studies suggest that any of MelQ, MelQx, or PhIP may increase the risk of certain cancers, but they were not associated with other types of cancers. In relation to IQ, published epidemiology studies provide some indication that human cancer risk is related to consumption of broiled or fried foods that may contain IQ and/or other HAAs (NTP 2004). So, a reduction to the exposure of these compounds has been recommended. In any case, it is important to have reliable data on the content of these HAAs in different types of foods prepared in several ways in order to assess the effects associated with their intake.

The present review collects bibliographic data from the last ten years, on the possible relationship between the intakes of certain foods and cancer risk. This paper belongs to a series of reviews on different aspects of heterocyclic amines, such as a) the occurrence and formation of HAAs during the cooking of food, mainly meat and fish products (Sanz Alaejos and Afonso); b) analytical methods applied to HAAs determination in foods (Sanz Alaejos et al. a); and c) HAAs intake, genetic aspects and human cancer risk (Sanz Alaejos et al. b).

\section{Possible relationships between HAAs and human cancer}

Epidemiological evidence appears to imply that an excessive consumption of very well-done red meat (HAAs-containing meat products), may induce certain types of cancer (Navarro et al. 2004; Nowell et al. 2002). "Red meat" usually refers to beef, veal, pork, mutton, and lamb. The so-called "processed meat" groups ham, cured or smoked meats, cold cuts, charcuterie, and meat-products.

The introduction of the Ames test in 1975 provided a rapid method to isolate potential carcinogens from food on the basis of their mutagenic activity. If comparing the mutagenic activity in meat samples to the one related to the known HAAs, most samples present mutagenic activity that cannot be exclusively associated to the aromatic amines currently identified. This suggests that additional compounds other than HAAs are present in these foods and need to be investigated, 
particularly those grilled over open flames (Anderson et al. 2005; Balbi et al. 2001; Jägerstad and Skog 2005).

Several epidemiological studies have been performed to test the hypothesis of an association between meat intake and human cancers (Zimmerli et al. 2001). It becomes really difficult to link meat consumption to the HAAs intake in practically all these studies. Many other substances and factors which possibly contribute to the etiologies of these cancers cannot be excluded, e.g. nitrosamines, polycyclic aromatic hydrocarbons (PAHs), acrylamide, high fat or salt intake, physical activity and others (Anderson et al. 2005; Augustsson et al. 1999; Balbi et al. 2001; De Stefani et al. 1997, 1998a, 2001; Gunter et al. 2005; Jägerstad and Skog 2005; Ji et al. 1995; LeMarchand et al. 1997, 2002; Murtaugh et al. 2004; Navarro et al. 2004; Nowell et al. 2002; Oreglia et al. 2001; Probsttensch et al. 1997; Singh and Fraser 1998; Sinha et al. 1998, 1999, 2001, 2005; Zheng et al. 1998).

Cancer development attributed to HAAs intake is shown in Table II together with some other dietary factors for comparison purposes.

Insert Table II about here

Table III shows the enhancing and protective effects exerted by dietary components on cancer risk development when associated with consumption of foods potentially containing HAAs. Usually, odds ratios (OR) are used. Sometimes relative risks (RR) are used, but in some studies no indication is made.

Insert Table III about here

Animal fat intake has been frequently, but inconsistently, associated to colorectal cancer risk. Intakes of total fat, saturated fat $(S)$, and polyunsaturated fat $(P)$ are not related with the risk of this disease. However, an inverse association is found for the P/S ratio. So, this ratio may be an indicator of colorectal cancer (LeMarchand et al. 1997). The fat content of red meat diminishes with the intensity of cooking. Therefore, potential higher risk associated with well-done beef may be 
counterbalanced with the lower fat content of meat. Red and total meat intakes are associated with strong increases in risk of squamous cell laryngeal cancer. This effect disappears after controlling the total fat intake. On the other hand, total fat intake displays a strong association with risk of laryngeal cancer when red meat is also included. Total fat intake combines its effect multiplicatively with tobacco smoking (Oreglia et al. 2001). However, MelQx consumption was inversely associated with smoking habits in relation to lung cancer. Neither DiMelQx nor PhIP show an association with smoking categories on lung cancer histology, and probably, are not associated with lung cancer risk (Sinha et al. 2000).

Vitamins $C$ and $E$, vegetables and fruits are associated with reduced risks of prostate and other cancers in population-based studies (Chan et al. 2005; Chiu et al. 2003; Deneo Pellegrini et al. 1999; De Stefani et al. 1998a; Hu et al. 1999; La Vecchia et al. 1996; Nomura et al. 2003; Sinha et al. 1999). The possible explanation is that vitamins $C$ and $E$ inhibit the nitrosation when nitrosamines or other $\mathrm{N}$-nitroso compounds are present in tissues. Also, fiber and carotene seem to exert a decline in cancer risk (Chiu et al. 2003; Deneo Pellegrini et al. 1999; Hu et al. 1999; Kampman et al. 1995; La Vecchia et al. 1996; Shannon et al. 1996; Singh and Fraser 1998; Slattery et al. 1997). However, in relation to pancreatic cancer, high intakes of grilled/barbecued red meat increase odds ratios, but no significant changes are further detected by adjustment the fruit, vegetables, calories, total fat, or alcohol consumption (Anderson et al. 2002). Although the high meat-low vegetable diet is considered the reference high-risk diet of colorectal cancer, other risk dietary patterns are emerging, such as high intakes of processed meat and refined carbohydrates. The strong association with refined cereal products is consistent with the hypothesis of a role of hyperinsulinism in colorectal carcinogenesis (Boutron-Ruault et al. 1999). Total dietary diversity is not associated with colon cancer (Slattery et al. 1997). However, eating a diet with a great diversity of meats, poultry, fish and eggs is associated with a $50 \%$ increase in risk among all the men. Women who eat a diet with a more diversified pattern of vegetables presented, approximately, a $20 \%$ lower risk than women who ate a non-diversified diet in vegetables (Slattery et al. 1997). 
There are few epidemiological studies in which an exclusive association between HAAs and human cancer can be assumed.

1. Red meat intake: Experts from the World Cancer Research Fund and the American Institute for Cancer Research (WCRF/AICR, 1997) reviewed data on red meat intake and cancer risk. Those experts concluded that a high intake of red meat probably increases the risk of developing colorectal cancer, and possibly increases the risk of pancreas, breast, prostate and kidney cancers.

Some reviews on meat consumption and cancer of the large bowel have been published (Norat and Riboli 2001; Truswell 2002). One of these reviews concludes that the relationship between meats and colorectal cancer looks generally weaker than the "probable" status stated by the WCRF in 1997. Nonetheless, it is possible that certain meats or sausages cooked at very high temperature can imply some risk (Truswell 2002). The hypothesis that consumption of red and processed meat increases colorectal cancer risk is reassessed in a meta-analysis of articles published during 1973-1999. Total meat consumption is not significantly associated with colorectal cancer risk (Kato et al. 1997; LeMarchand et al. 2002; Navarro et al. 2003; Norat and Riboli 2001; Sinha et al. 1999, 2005), but high intake of red meat, and particularly of processed meat, is associated with a moderate increase on colorectal cancer risk in all sexes (LeMarchand et al. 2002; Norat and Riboli 2001; Sinha et al. 1999), or only in men (LeMarchand et al. 1997). Sinha et al. (1999) found a higher risk of colorectal adenoma mostly confined to intake of well-done/very welldone red meat and meats cooked at high temperature, such as grilled and, possibly, fried red meat. However, other authors (Navarro et al. 2003) do not find any relation between high consumption of total-, red- and fatty beef meats with colorectal cancer risk. A slight increase in risk is detected for relatively high intake of cold cuts, sausages and bovine viscera, whereas lean beef is associated with a decreased risk (Navarro et al. 2003).

Other investigations show that red meat intake is unrelated to colon cancer (LeMarchand et al. 2002; Sinha et al. 2005) although individuals with low intake present lower risk for rectal cancer (LeMarchand et al. 2002). Three wide studies were performed in Norway (Gaard et al. 1996) and Sweden (Augustsson et al. 1999; Larsson et al. 1996). Although in these countries the HAA 
concentrations in the diet are usually lower than in other western European countries, differences are found when high consumption (Augustsson et al. 1999; Larsson et al. 1996) or very high frequency of consuming (Gaard et al. 1996) are studied. So, high frequency of sausages consumption shows a relative risk of colon cancer of 3.5 (95\% Cl: 1.02-11.9) only for women. The $\mathrm{RR}$ for total meat consumption is 1.87 . However, both parameters are not statistically significant for men (Gaard et al. 1996). In the prospective study for 61433 Swedish women, with ages between 40 and 75 years, a significant positive association between red meat consumption and risk of distal colon cancer is observed, but not of cancers of proximal colon nor rectum (Larsson et al. 1996). In a case-control study, risks for colon and rectal cancers are lower for the highest estimated intake category than for the lowest intake category of HAAs. Relative risks for each one of the HAAs are similar. Intake of meat and fish together, without considering the cooking method, is associated with increased risk of colon and bladder cancer (Augustsson et al. 1999).

Consumption of white meats is generally associated with lower cancer rates, even when these meats have HAAs contents greater than red meats (Sanz Alaejos and Afonso). Furthermore, chicken eaten without skin seems to decrease colorectal cancer risk (LeMarchand et al. 1997). Red meat is no more implicated than any other meat type (Kampman et al. 1999; LeMarchand et al. 2002; Sinha et al. 2000, 2005).

2. Cooking methods: The influence of cooking methods and cancer risk was also evaluated by the WCRF/AICR (1997). The report established that there is not convincing evidence that any cooking method modifies the risk of any cancer; neither there is evidence of any probably causal relationship. However, high intakes of grilled/barbecued red meat possibly increase the risk of stomach and colorectal cancer (WCRF/AICR, 1997). Higher risks are also observed for methods that require higher temperatures and close contact of the food to the heating source, such as barbecuing or iron-pan cooking and especially for red meats. Iron-pan means a kind of ground cast iron skillet used in Argentina to cook meat without adding oil or fat. No associations are found for boiled meats (Navarro et al. 2004). 
However, the results of studies on cooking methods are not consistent. Cooking methods hypothetically considered "hazardous", such as frying and broiling, were found to increase colorectal cancer risk in some studies but not in others (Jägerstad and Skog 2005; LeMarchand et al. 2002; Navarro et al. 2004; Norat and Riboli 2001). The association between colorectal cancer and total HAAs intake is limited to men, and it is more clearly observed with MelQx. This relation with MelQx seems to result partially from an association with pan-fried meat and fish (LeMarchand et al. 2002). Furthermore, MelQx intake is associated with slightly increased risk of lung cancer. However, DiMelQx and PhIP intakes show no association (Sinha et al. 2000). When various factors are controlled, such as total-, red-, barbecued- or smoked meat, a statistically significant lung cancer risk associated to MelQx remains. This MelQx effect is still present, but no longer statistically significant, when the model includes well-done- or fried red meat. The opposite is also true; the previously significant effects of well-done and fried red meat are no longer significant after adjusting for MeIQx (Terry et al. 2003). Grilling/barbecuing, oven broiling or intakes of well-done meat and fish do not appear to affect cancer risk (LeMarchand et al. 2002; Sinha et al. 2000). The exception appears when a darkly browned surface is preferred but excluding red roasted meat. Roasted chicken and all barbecued meats were associated with a risk for colorectal cancer (Navarro et al. 2004). Pancreatic cancer cases reported high levels of grilled/barbecued meat intake and low levels of broiled meat intake relative to controls. Other meat variables do not show statistically significant associations with risk, neither alter the findings for barbecued meat intake. These meat variables include processed-, total-, total broiled-, total fried-, total red-, or total meat cooked by means other than grilling (Anderson et al. 2002). In a population-based case-control study (Anderson et al. 2005), dietary intake of HAAs and benzo(a)pyrene formed in grilled/barbecued red meat and fried red meat, was studied in relation to pancreatic cancer. Cases, when compared with controls, had higher mean levels of all the carcinogens studied (PhIP, MelQx, DiMelQx, and benzo(a)pyrene), as well as total mutagenic activity. The highest ORs were seen in the highest quintiles of intake and, with the exception of MelQx, there were all statistically significant. Grilled/barbecued red meat intake was a statistically significant predictor of pancreatic 
cancer risk. Fried red meat intake also increased risk, but was not statistically significant, because fried meats in general do not contain appreciable concentrations of PAHs (Anderson et al. 2005).

3. Doneness: Meat doneness was weakly and inconsistently associated with prostate cancer risk for individual types of meat, but an increased risk was observed for very well-done beefsteak (Norrish et al. 1999). The incidence rates of prostate, pancreas and colon cancers seem to be positively related to exposure to HAAs among men of different races in Los Angeles County (USA). This result can partially explain the higher incidence among blacks with respect to white men in the studied human group, because black men consume higher amounts of well-done meats, bacon, pork and cold cuts (Bogen and Keating 2001). Moreover, an increased risk of breast cancer is observed in healthy women who consume very well-done meats. PhIP is detected in their milks at levels of $59 \mathrm{pg} / \mathrm{mL}$, but not in milk from a vegetarian donor. Preference for well-done red meat is not significantly associated with colon cancer, but seems to increase risk somewhat for rectal cancer (LeMarchand et al. 2002; Sinha et al. 1999). On the other hand, MelQx, PhIP, and benzo\{a\}pyrene were associated with a slight increased risk of adenoma of colon, non-advanced adenoma, and single adenomas in a recent and wide population-based case-control study, related to a high intake of well-done red meat, bacon and sausage. However, in a fully adjusted model, total mutagenicity, DiMelQx, and MelQx intakes are not associated with colorectal adenoma risk when all adenomas were combined. Rectal cancer is not associated with any of the meat variables, such as meat types or doneness/cooking methods (Sinha et al. 2005). Pancreatic cancer cases reported slightly higher mean levels of intake for total-, total red-, and processed meat, and lower mean levels of intake for white meat, when comparing with controls. The relative amounts of meat intake by doneness levels are not different between cases and controls (Anderson et al. 2002). However, other studies have shown no such association among well-done red meat consumption and cancer (Augustsson et al. 1999; Gunter et al. 2005; Kampman et al. 1999; Norrish et al. 1999; Sinha et al. 2000, 2001).

As conclusion, in general, the three high-temperature cooking methods (pan-frying, ovenbroiling and grilling/barbecuing) seem to produce the highest HAAs concentrations. Preparation methods like boiling, oven roasting, deep-frying, and charcoal grilling are generally "milder", and 
much lower amounts of HAAs are formed. The degree of doneness, which is often closely related to surface browning and total cooking time, is a key issue for HAAs production in cooked meat. The formation of the crust is the result of steady transportation of water and dissolved compounds such as amino acids and creatinine to the surface by capillary flow to the evaporation zone. Thus, the precursors of HAAs are concentrated on or near the surface of the meat where the temperature is highest.

However, there is insufficient scientific evidence to prove that these genotoxic compounds really cause human cancer, and so, no limits have been set for their presence in cooked foods. Nevertheless, the competent authorities in most Western countries recommend minimizing their occurrence. The reasons are the co-existence of other mutagens/carcinogens in foods, and the possibility that the HAAs induce mutations, therefore increasing the sensitivity to tumor promoters. So, some recommendations could be followed: Choose lean cuts. Apply lower temperatures and shorter cooking times. Avoid browning of foods or, at least, remove the crust and charred parts of fried of grilled meat, poultry and fish. Do not allow drippings from meat to become dry before making gravy. To lessen the levels of HAAs produced it may be useful cooking meat and fish together with foodstuffs containing phenolic antioxidants or with tomatoes, carrots or other vegetables rich of carotenoids and antioxidant vitamins.

\section{Uncertainties associated to epidemiological results}

The lack of consistency of the results for all types of meats together with the lack of information from cohort studies do not always permit a judgment about the possible differences in the effect of meat on e.g., colon and rectal cancer risks, separately (Norat and Riboli 2001). In any case, the present data are not enough to evaluate the dose response of the possible relationship between HAAs and human cancer, in its widest sense. Besides, a simplistic approach to evaluate only HAAs with respect to cancer risk may not be too appropriate, taking into account that diet is a complex mixture that contains carcinogens, co-carcinogens and anti-carcinogens (Jägerstad and Skog 2005; 
Matos and Brandani 2002; Sinha and Rothman 1999; Sugimura et al. 1996). Furthermore, it must be noticed that the development of cancer takes a long time, and so there is a delay of several years between exposure and disease outcome.

Metabolic aspects of HAAs have been reviewed (Gooderham et al. 2001; Sanz Alaejos et al. b). The major pathway for the metabolic activation of HAAs starts with the N-hydroxylation of the exocyclic amino group, catalyzed mainly by cytochrome P450 1A2 (CYP1A2). Although these metabolites may directly react with DNA, this N-hydroxylation step is usually followed by sulphation or acetylation by means of sulfotransferase $1 \mathrm{~A} 1$ (SULT1A1), or N-acetyltransferases (NAT), respectively (Sanz Alaejos et al. b).

Urinary excretion of MelQx and its metabolites has been also studied (Ji et al. 1994; Lynch et al. 1992; Sinha et al. 1995; Stillwell et al. 1994, 1999a, 1999b; Turesky et al. 1998). MelQx metabolism and disposition in humans are more strongly influenced by CYP1A2 activity than those of PhIP. Biotransformation of MelQx via CYP1A2 oxidation to form $8-\mathrm{CH}_{2} \mathrm{OH}-\mathrm{MelQx}$ and the hydroxylamine $\mathrm{NHOH}-\mathrm{MelQx}$, followed by N-2-glucuronidation is a general pathway for the MelQx metabolism in humans. The formation of both $8-\mathrm{CH}_{2} \mathrm{OH}-\mathrm{MeIQx}$ and $\mathrm{NHOH}-\mathrm{MeIQx}$ is catalyzed by CYP1A2 and may be useful biomarkers of CYP1A2 activity in humans (Turesky et al. 1998). Low levels of total unconjugated MelQx are associated with high CYP1A2 activity when adjusted for amount of ingested meat, whereas NAT2 activity shows no relationship with the latter (Sinha et al. 1995). However, significant interracial differences are observed for black, white and Asian men. This is because urinary levels of MelQx are positively associated with intake frequencies of pork, bacon and cold cuts (Ji et al. 1994).

The theoretical cancer risk by HAAs in the Swiss diet is calculated by two different procedures and results in $0.7 \cdot 10^{-5}$ or, roughly, $10^{-5}$ (Zimmerli et al. 2001). If it is assumed that humans may be 10 to 100 times more susceptible to HAAs than male rats, the hypothetical excess cancer risk would be in the order of $10^{-4}$ to $10^{-3}$. Cancer potency estimates for several of the HAAs were as high as one in a 100,000 per ppb in the total diet. Based on HAAs exposures ranges of 0.02 to 83 ppb in the human total diet, and rodent data, Gaylor and Kadlubar (1991) estimated that 
the upper limit on cancer risk due to HAAs formed during cooking is on the order of one per 10,000 . Although rodents, monkeys and humans have the capacity to activate HAAs, studies using hepatic microsomes demonstrated that humans have a greater capacity to activate HAAs than rodents or cynomolgus monkeys. Human risk, based on linear extrapolation of $\mathrm{TD}_{50}$ calculations from mouse, rat, or primate tumor data, and on mean estimated mutagen exposures for the U.S. population, suggests potential risks of $10^{-5}$ to $10^{-3}$ (Bogen 1994; Felton et al. 1992; Gaylor and Kadlubar 1991; Layton et al. 1995). Adamson (1996) suggests potential risks of $10^{-4}$ to $10^{-3}$. On the other hand, interspecies differences in CYP1A2 enzyme expression and catalytic activities may be significant and must be carefully considered when assessing human health risk (Kim and Guengerich 2005). So, important differences between human and rat CYP1A2 were found in the C8- and N-oxidation of MelQx (Turesky et al. 2001), and in the levels of expression and catalytic activities for HAAs Nhydroxylation (Turesky et al. 1999), although rat and human CYP1A2 have identical 75\% amino acid sequence (Guengerich 1997). The value $10^{-3}$ is considered as a maximum credible risk (Felton et al. 1992). Similar theoretical cancer risks result from human exposure to other compounds unavoidably present in the diet, such as naturally occurring radionuclides (potassium 40) or excess calories (Zimmerli et al. 2001).

There are several major uncertainties in the present estimation of cancer risk, including human susceptibility, exposure, carcinogenic potencies of individual HAA, as well as possible interactions between different HAAs and other substances normally present in a diversified diet. The most likely target organs for most HAAs are the liver and the gastrointestinal tract. Nevertheless, in Switzerland the cancer mortality trends for these organs (gastric and colon cancers) show a permanent slight decrease, although meat, fish and alcohol consumption have greatly increased in Switzerland over the last 50 years, and milk intake (including yogurt) has decreased (Zimmerli et al. 2001).

A major trouble of the epidemiological studies is the obtaining of a correct estimation for the exposure to HAAs (Alexander et al. 2002; Keating and Bogen 2001; Keating et al. 1999; Sinha and Rothman 1997; Skog 2002). Dietary assessment in combination with analytical data on HAAs levels 
in various foods must be used. In this sense, food frequency questionnaires including not only the type and amount of foods consumed but also the cooking methods and the level of doneness are required. There are several flaws including bias, inconsistent reporting, difficulty in quantifying cooking doneness by such methods, and the day-to-day variation in the diet. Moreover, HAAs belong to a class of numerous compounds and the quantification of each of them in a large number and variety of food samples is not an easy task. Consequently, it is not surprising that bibliographic data are very incomplete (Sanz Alaejos and Afonso). Table IV shows some estimates for HAAs mean intakes in various countries. The dispersion of the results is evident, and there are scarce data referred to individual HAAs.

Insert Table IV about here

Some attempts have been made to develop biomarkers in order to overcome some of the problems associated with the use of questionnaires in the assessment of HAAs exposure. Biomarkers of diet promise to provide a more accurate measure of dietary intake. They are more objective because they do not rely on the subject's memory when being interviewed, or on the accuracy of recording the food diary. The use of biomarkers does not solve the problem of exposure estimation back in time for years, since HAAs do not accumulate in body tissues. Hence, HAAs in body fluids or tissues would only give a measure of recent exposure (Frandsen et al. 2002; Lynch et al. 1992; Stillwell et al. 1997; Strickland et al. 2001; Wild et al. 2001). However, these short-term markers are useful tools to study mechanisms of action of HAAs, and to validate questionnaires (Sinha 2002). So, Peters et al. (2003) when combining the measurements of urinary mutagenicity and the estimated intake of meat-derived mutagenicity, found a stronger positive association with risk for colorectal adenomas than did either variable separately, when comparing the highest with the lowest quintile of combined mutagenicity $(\mathrm{OR}=5.6 ; 95 \% \mathrm{Cl}=2.3-13.9)$. In consequence, urinary mutagenicity may be considered a useful adjunct to questionnaire data and may have value as a direct biomarker of exposure and/or risk for colorectal adenoma (Peters et al. 
2003). Also, the formation of both $8-\mathrm{CH}_{2} \mathrm{OH}-\mathrm{MeIQx}$ and $\mathrm{NHOH}-\mathrm{MelQx}$ may be useful biomarkers of CYP1A2 activity in humans (Turesky et al. 1998).

On the other hand, protein adducts in blood and HAAs in hair are biomarkers reflecting longer-term exposure. The use of PhIP (and other HAAs) in hair is attractive. It would integrate the dose over several months depending on the length of the hair, which grows approximately $1 \mathrm{~cm}$ per month. Hair is easy to sample and store for the purpose of later analysis in prospective studies on the relationship between HAAs exposure and cancer (Alexander et al. 2002; Kobayashi et al. 2005).

A main problem when using literature data related to HAAs contained in cooked dishes is that many experiments have been performed under unspecified cooking conditions, or using high cooking temperatures during a long time to maximize the HAAs production. This last case can lead to a non-representative form of the usual way of cooking meats by the general population in a certain country. The relation between the degree of doneness and the surface browning may differ because some people fry their meats at a high temperature for a short time to get a brown surface but the interior is not so cooked through, while others fry their meats at low temperatures but during a longer time. This can lead to the same degree of surface browning but very different HAAs amounts. The colored photos are sometimes used to assess the preference of the consumer on the degree of doneness and, indirectly, the amount of HAAs (Alexander et al. 2002; Keating and Bogen 2001; Keating et al. 1999; Sinha and Rothman 1997; Skog 2002). The results seem to lead to an underestimation of exposure (Skog 2002). However, HAAs levels in home-cooked meat samples are significantly different when samples are visually classified for doneness, but not when selfreported doneness preference is used to classify doneness or to categorize samples (Keating et al. 2000). HAAs levels in meats obtained from homes vary considerably from the laboratory data. In a study (Knize et al. 2002), samples were taken from volunteers responding in survey that they preferred their meat well-done or very well-done, leading to expect high HAAs exposures in these households. But, surprisingly, in that collection of meats samples, approximately $25 \%$ of the samples had undetectable amounts of MelQx or PhIP. Besides, although well-done chicken breast prepared in the laboratory may contain large amounts of PhIP, a survey of flame-grilled meat 
samples cooked in private homes showed PhIP levels in beefsteak and chicken breast that were not significantly different. The extremely high PhIP levels reported in some studies of grilled chicken are not observed in home-cooked samples (Knize et al. 2002). Considerable differences between equivalent products from different manufacturers are found in many cases. In addition, the terminology used for different cooking methods varies around the world. In Argentina and Uruguay the term "roasting/broiling" does not expose foods directly to flame, whereas "grilling" may use a hot surface (i.e., a pre-heated heavy iron plate), or a grill directly above burning coals (Matos and Brandani 2002; Navarro et al. 2004). Cooking practices and eating habits differ between different populations, and conclusions drawn from one population may not be applicable to another (Alexander et al. 2002; Ferguson 2002; Keating and Bogen 2001, 2004; Keating et al. 1999; Matos and Brandani 2002; Sinha and Rothman 1997; Skog 2002). In some countries pan residues are used for preparing gravies, and pan residues contain substantial amounts of HAAs compared with the corresponding food item. Besides, meat extracts and bouillon (cubes) contribute to the HAAs intake. Therefore, it is important to establish databases on HAAs content in cooked foods that are representative for the eating habits of the population being studied, and taking into account each ingredient of the recipe, spices, condiments, etc. The dishes should be prepared in a way that reflects regular household and restaurant cooking conditions.

Really, recent advances in the analytical instrumentation, concretely in LC-MS and GC-MS, have greatly facilitated the ability to measure HAAs in foods, as well as HAAs and their metabolites in urine of meat eaters. Nevertheless, the accurate determination of HAAs is a difficult analytical task since traces of these compounds have to be determined in highly complex food matrices. This problem can only be solved by combining both elaborate sample preparation steps with selective separation steps, and then followed by sensitive detection methods to quantify low levels of HAAs. Tedious clean-up procedures that include extraction, purification, and pre-concentration steps, followed by a separation technique, such as liquid or gas chromatography and capillary electrophoresis are usually used. The main detection systems used are UV, fluorescence, electrochemical and MS (Sanz Alaejos et al. a). In addition, the different analytical methods applied 
might not be comparable. Some problems in determining appropriate estimates of extraction recovery rates must also be taken into account. Some HAAs or HAAs derivatives can bind with other food components. All of these formed compounds cannot be extracted from food by the usual extraction methods and, therefore, the dietary assessment of genotoxic compounds may be underestimated. Therefore, different extraction procedures have to be applied to cooked and uncooked meat, before and after enzymatic proteolysis. Consequently, the use of absolute or relative values of HAAs content in food can lead to erroneous conclusions when possible cancer risks are established for the intake of these foods.

Divergent results can be due to several causes, one of them is the meat type and the ingredients added. Also, analytical results on HAAs content in foods obtained under unspecified cooking conditions or at high cooking temperatures may be not representative. It should very convenient: a) to establish databases on HAAs content in cooked foods that are representative for the eating habits of the population being studied, and taking into account each ingredient of the recipe; b) to record the inside and outside food appearance in the food frequency questionnaires, instead of simply recording the "doneness level"; c) to consider the possible role of HAAs in the cancer development in conjunction with PAHs and other toxic compounds; and d) to use biomarkers in order to determine the HAAs exposure.

\section{References}

Adamson RH, Thorgeirsson UP, Sugimura T. 1996. Extrapolation of heterocyclic amine carcinogenesis data from rodents and nonhuman primates to humans. Archives of Toxicology Supplement 18:303-318.

Alexander J, Reistad R, Hegstad S, Frandsen H, Ingebrigtsen K, Paulsen JE, Becher G. 2002. Biomarkers of exposure to heterocyclic amines: approaches to improve the exposure assessment. Food and Chemical Toxicology 40:1131-1137. 
Anderson KE, Kadlubar FF, Kulldorff M, Harnack L, Gross M, Lang NP, Barber C, Rothman N, Sinha R. 2005. Dietary intake of heterocyclic amines and benzo(a)pyrene: Associations with pancreatic cancer. Cancer Epidemiology, Biomarkers \& Prevention 14:2261-2265.

Anderson KE, Sinha R, Kulldorff M, Gross M, Lang NP, Barber C, Harnack L, DiMagno E, Bliss R, Kadlubar FF. 2002. Meat intake and cooking techniques: associations with pancreatic cancer. Mutation Research 506-507:225-231.

Augustsson K, Skog K, Jägerstad M, Dickman PW, Steineck G. 1999. Dietary heterocyclic amines and cancer of the colon, rectum, bladder, and kidney: a population-based study. The Lancet 353:703-707.

Augustsson K, Skog K, Jägerstad M, Steineck G. 1997. Assessment of the human exposure to heterocyclic amines. Carcinogenesis 18:1931-1935.

Balbi JC, Larrinaga MT, De Stefani E, Mendilaharsu M, Boffetta P, Brennan P. 2001. Food and risk of bladder cancer: a case-control study in Uruguay. European Journal of Cancer Prevention 10:453-458.

Barrett JH, Smith G, Waxman R, Gooderham N, Lightfoot T, Garner RC, Augustsson K, Wolf CR, Bishop DT, Forman D. 2003. Investigation of interaction between $\mathrm{N}$-acetyltransferase 2 and heterocyclic amines as potential risk factors for colorectal cancer. Carcinogenesis 24:275-282.

Bogen KT. 1994. Cancer potencies of heterocyclic amines found in cooked foods. Food and Chemical Toxicology 32:505-515.

Bogen KT, Keating GA. 2001. US dietary exposures to heterocyclic amines. Journal of Exposure Analysis and Environmental Epidemiology 11:155-168.

Bosetti C, La Vecchia C, Talamini R, Negri E, Levi F, Dal Maso L, Franceschi S. 2002a. Food groups and laryngeal cancer risk: a case-control study from Italy and Switzerland. International Journal of Cancer 100:355-360.

Bosetti C, La Vecchia C, Talamini R, Simonato L, Zambon P, Negri E, Trichopoulos D, Lagiou P, Bardini R, Franceschi S. 2000. Food groups and risk of squamous cell esophageal cancer in northern Italy. International Journal of Cancer 87:289-294. 
Bosetti C, Negri E, Franceschi S, Pelucchi C, Talamini R, Montella M, Conti E, La Vecchia C. 2001. Diet and ovarian cancer risk: a case-control study in Italy. International Journal of Cancer 93:911-915.

Bosetti C, Talamini R, Levi F, Negri E, Franceschi S, Airoldi L, La Vecchia C. 2002b. Fried foods: a risk factor for laryngeal cancer? British Journal of Cancer 87:1230-1233.

Boutron-Ruault MC, Senesse P, Faivre J, Chatelain N, Belghiti C, Meance S. 1999. Food as risk factors for colorectal cancer: a case-control study in Burgundy (France). European Journal of Cancer Prevention 8:229-235.

Butler LM, Sinha R, Millikan RC, Martin CF, Newman B, Gammon MD, Ammerman AS, Sandler RS. 2003. Heterocyclic amines, meat intake, and association with colon cancer in a populationbased study. American Journal of Epidemiology 157:434-445.

Chan JM, Gann PH, Giovannucci EL. 2005. Role of diet in prostate cancer development and progression. Journal of Clinical Oncology 23:8152-8160.

Chao A, Thun MJ, Connell CJ, McCullough ML, Jacobs EJ, Flanders WD, Rodríguez C, Sinha R, Calle EE. 2005. Meat consumption and risk of colorectal cancer. JAMA 293:172-182.

Chiu BCH, Ji BT, Dai Q, Gridley G, McLaughlin JK, Gao YT, Fraumeni JF, Chow WH. 2003. Dietary factors and risk of colon cancer in Shanghai (China). Cancer Epidemiology, Biomarkers \& Prevention 12:201-208.

Dai Q, Shu XO, Jin F, Gao YT, Ruan ZX, Zheng W. 2002. Consumption of animal foods, cooking methods and risk of breast cancer. Cancer Epidemiology, Biomarkers \& Prevention 11:801-808.

Deneo Pellegrini H, De Stefani E, Ronco A, Mendilaharsu M. 1999. Food, nutrients and prostate cancer: a case-control study in Uruguay. British Journal of Cancer 80:591-597.

Deneo Pellegrini H, De Stefani E, Ronco A, Mendilaharsu M, Carzoglio K. 1996. Meat consumption and risk of lung cancer: a case-control study from Uruguay. Lung Cancer 14:195-205.

De Stefani E, Fierro L, Mendilaharsu M, Ronco A, Larrinaga MT, Balbi JC, Alonso S. 1998a. Meat intake, "mate" drinking and renal cell cancer in Uruguay: a case-control study. British Journal of Cancer 78:1239-1243. 
De Stefani E, Ronco A, Brennan P, Boffetta P. 2001. Meat consumption and risk of stomach cancer in Uruguay: a case-control study. Nutrition and Cancer 40:103-107.

De Stefani E, Ronco A, Mendilaharsu M, Deneo Pellegrini H. 1998b. Case-control study on the role of heterocyclic amines in the ethiology of upper aerodigestive cancers in Uruguay. Nutrition and Cancer 32:43-48.

De Stefani E, Ronco A, Mendilaharsu M, Guidobono M, Deneo Pellegrini H. 1997. Meat intake, heterocyclic amines and risk of breast cancer: a case-control study in Uruguay. Cancer Epidemiology, Biomarkers \& Prevention 6:573-581.

Felton JS, Knize MG, Roper M, Fultz E, Shen NH, Turteltaub KW. 1992. Chemical analysis, prevention, and low-level dosimetry of heterocyclic amines from cooked food. Cancer Research 52:S2103-S2107.

Ferguson LR. 2002. Meat consumption, cancer risk and population groups within New Zealand. Mutation Research 506-507:215-224.

Franceschi S, Favero A, La Vecchia C, Negri E, Conti E, Montella M, Giacosa A, Nanni O, Decarli A. 1997. Food groups and risk of colorectal cancer in Italy. International Journal of Cancer 72:56-61.

Frandsen H, Frederiksen H, Alexander J. 2002. 2-Amino-1-methyl-6-(5-hydroxy-)phenylimidazo[4,5b]pyridine (5-OH-PhIP), a biomarker for the genotoxic dose of the heterocyclic amine 2-amino1-methyl-6-phenylimidazo[4,5-b]pyridine (PhIP). Food and Chemical Toxicology 40:1125-1130.

Gaard M, Tretli S, Loken EB. 1996. Dietary factors and risk of colon cancer: a prospective study of 50,535 young Norwegian men and women. European Journal of Cancer Prevention 5:445-454.

Galeone C, Pelucchi C, Talamini R, Levi F, Bosetti C, Negri E, Franceschi S, La Vecchia C. 2005. Role of fried foods on oral/pharyngeal and oesophageal cancers. British Journal of Cancer 92:2065-2069.

Gaylor DW, Kadlubar F. 1991. Quantitative cancer risk assessment of heterocyclic amines in cooked foods. In: Hayatsu $\mathrm{H}$, Hayatsu $\mathrm{H}$, editors. Mutagens in food: detection and prevention. Boca Ratón FL: CCR Press. p 229-236. 
Gooderham NJ, Murray S, Lynch AM, Yadollahi-Farsani M, Zhao K, Boobis AR, Davies DS. 2001. Food-derived heterocyclic amine mutagens: Variable metabolism and significance to humans. Drug Metabolism and Disposition 29:529-534.

Guengerich FP. 1997. Comparison of catalytic selectivity of cytochrome P450 subfamily members from different species. Chemico-Biological Interactions 106:161-182.

Gunter MJ, Probst-Hensch NM, Cortessis VK, Kulldorff M, Haile RW, Sinha R. 2005. Meat intake, cooking-related mutagens and risk of colorectal adenoma in a sigmoidoscopy-based casecontrol study. Carcinogenesis 26:637-642.

Hu JF, La Vecchia C, Negri E, Chatenoud L, Bosetti C, Jia XY, Liu RZ, Huang GR, Bi DZ, Wang CX. 1999. Diet and brain cancer in adults: a case-control study in northeast China. International Journal of Cancer 81:20-23.

International Agency for Research on Cancer. 1993. Some Naturally Occurring Substances. In: IARC Monographs of the Evaluation of the Carcinogenic Risk of Chemicals to Humans. Food Items and Constituents: Heterocyclic aromatic amines and mycotoxins. Lyon. Vol. 56.

Jägerstad M, Skog K. 2005. Genotoxicity of heat-processed foods. Mutation Research 574:156172.

Ji BT, Chow WH, Gridley G, McLaughlin JK, Dai Q, Wacholder S, Hatch MC, Gao YT, Fraumeni JF. 1995. Dietary factors and the risk of pancreatic cancer. A case-control study in Shanghai, China. Cancer Epidemiology, Biomarkers \& Prevention 4:885-893.

Ji H, Yu MC, Stillwell WG, Skipper PL, Ross RK, Henderson BE, Tannenbaum SR. 1994. Urinary excretion of 2-amino-3,8-dimethyl-imidazo[4,5-f]-quinoxaline in white, black, and Asian men in Los Angeles County. Cancer Epidemiology, Biomarkers \& Prevention 3:407-411.

Kampman E, Slattery ML, Bigler J, Leppert M, Samowitz W, Caan BJ, Potter JD. 1999. Meat consumption, genetic susceptibility, and colon cancer risk: a United States multicenter casecontrol study. Cancer Epidemiology, Biomarkers \& Prevention 8:15-24. 
Kampman E, Verhoeven D, Sloots L, VantVeer P. 1995. Vegetable and animal products as determinants of colon-cancer risk in Dutch men and women. Cancer Causes \& Control 6:225234.

Kato I, Akhmedkhanov A, Koenig K, Toniolo PG, Shore RE, Riboli E. 1997. Prospective study of diet and female colorectal cancer: The New York University women's health study. Nutrition and Cancer 28:276-281.

Keating GA, Bogen KT. 2001. Methods for estimating heterocyclic amine concentrations in cooked meats in the US diet. Food and Chemical Toxicology 39:29-43.

Keating GA, Bogen KT. 2004. Estimates of heterocyclic amine intake in the US population. Journal of Chromatography B 802:127-133.

Keating GA, Layton DW, Felton JS. 1999. Factors determining dietary intakes of heterocyclic amines in cooked foods. Mutation Research 443:149-156.

Keating GA, Sinha R, Layton D, Salmon CP, Knize MG, Bogen KT, Lynch CF, Alavanja M. 2000. Comparison of heterocyclic amines levels in home-cooked meats with exposure indicators (United States). Cancer Causes \& Control 11:731-739.

Kim D, Guengerich FP. 2005. Cytochrome P450 activation of arylamines and heterocyclic amines. Annual Review of Pharmacology and Toxicology 45:27-49.

Knize MG, Kulp KS, Salmon CP, Keating GA, Felton JS. 2002. Factors affecting human heterocyclic amine intake and the metabolism of PhIP. Mutation Research 506-507:153-162.

Kobayashi M, Hanaoka T, Hashimoto H, Tsugane S. 2005. 2-Amino-1-methyl-6-phenylimidazo[4,5b]pyridine (PhIP) level in human hair as biomarker for dietary grilled/stir-fried meat and fish intake. Mutation Research 588:136-142.

Larsson SC, Rafter J, Holmberg L, Bergkvist L, Wolk A. 2005. Red meat consumption and risk of cancers of the proximal colon, distal colon and rectum. The Swedish Mammography Cohort. International Journal of Cancer 113:829-834. 
La Vecchia C, Ferraroni M, Mezzetti M, Enard L, Negri E, Franceschi S, Decarli A. 1996. Attributable risks for colorectal cancer in northern Italy. International Journal of Cancer 66:6064.

Layton DW, Bogen KT, Knize MG, Hatch FT, Johnson VM, Felton JS. 1995. Cancer risk of heterocyclic amines in cooked foods. An analysis and implications for research. Carcinogenesis $16: 39-52$.

LeMarchand L, Hankin JH, Pierce LM, Sinha R, Nerurkar PV, Franke AA, Wilkens LR, Kolonel LN, Donlon T, Seifried A, Custer LJ, Lum-Jones A, Chang W. 2002. Well-done red meat, metabolic phenotypes and colorectal cancer in Hawaii. Mutation Research 506-507:205-214.

LeMarchand L, Wilkens LR, Hankin JH, Kolonel LN, Lyu LC. 1997. A case-control study of diet and colorectal cancer in a multiethnic population in Hawaii (United States): lipids and foods of animal origin. Cancer Causes \& Control 8:637-648.

Levi F, Pasche C, La Vecchia C, Lucchini F, Franceschi S. 1999. Food groups and colorectal cancer risk. British Journal of Cancer 79:1283-1287.

Levi F, Pasche C, La Vecchia C, Lucchini F, Franceschi S, Monnier P. 1998. Food groups and risk of oral and pharyngeal cancer. International Journal of Cancer 77:705-709.

Lynch AM, Knize MG, Boobis AR, Gooderham NJ, Davies DS, Murray S. 1992. Intra- and interindividual variability in systemic exposure in humans to 2-amino-3,8-dimethyl-imidazo[4,5f]quinoxaline and 2-amino-1-methyl-6-phenylimidazo[4,5-b]pyridine, carcinogens present in cooked beef. Cancer Research 52:6216-6223.

Matos E, Brandani A. 2002. Review on meat consumption and cancer in South America. Mutation Research 506-507:243-249.

Murtaugh MA, Ma KN, Sweeny C, Caan BJ, Slattery ML. 2004. Meat consumption patterns and preparation, genetic variants of metabolic enzymes, and their association with rectal cancer in men and women. Journal of Nutrition 134:776-784.

Navarro A, Díaz MP, Muñoz SE, Lantieri MJ, Eynard AR. 2003. Characterization of meat consumption and risk of colorectal cancer in Córdoba, Argentina. Nutrition 19:7-10. 
Navarro A, Muñoz SE, Lantieri MJ, Díaz MP, Cristaldo PE, de Fabro SP, Eynard AR. 2004. Meat cooking habits and risk of colorectal cancer in Córdoba, Argentina. Nutrition 20:873-877.

Nomura AMY, Hankin JH, Kolonel LN, Wilkens LR, Goodman MT, Stemmermann GN. 2003. Casecontrol study of diet and other risk factors for gastric cancer in Hawaii (United States). Cancer Causes \& Control 14:547-558.

Norat T and Riboli E. 2001. Meat consumption and colorectal cancer: a review of epidemiologic evidence. Nutrition Reviews 59:37-47.

Norrish AE, Ferguson LR, Knize MG, Felton JS, Sharpe SJ, Jackson RT. 1999. Heterocyclic amine content of cooked meat and risk of prostate cancer. Journal of the National Cancer Institute $91: 2038-2044$.

Nowell S, Coles B, Sinha R, MacLeod S, Ratnasinghe DL, Stotts C, Kadlubar FF, Ambrosone CB, Lang NP. 2002. Analysis of total meat intake and exposure to individual heterocyclic amines in a case-control study of colorectal cancer: contribution of metabolic variation to risk. Mutation Research 506-507:175-185.

Nowell S, Ratnasinghe DL, Ambrosone CB, Williams S, Teague-Ross T, Trimble L, Runnels G, Carrol A, Green B, Stone A, Johnson D, Greene G, Kadlubar FF, Lang NP. 2004. Association of SULT1A1 phenotype and genotype with prostate cancer risk in African-Americans and Caucasians. Cancer Epidemiology, Biomarkers \& Prevention 13:270-276.

NTP Report on Carcinogens, Tenth Edition. 2002. U.S. Department of Health and Human Services. Public Health Service. National Toxicology Program.

NTP Report on Carcinogens, Eleventh Edition. 2004. U.S. Department of Health and Human Services. Public Health Service. National Toxicology Program. p. 135-138.

Olsson V, Skog K, Lundström K, Jagërstad M. 2005. Colour photographs for estimation of heterocyclic amine intake from fried pork chops of different RN genotypes indicate large variations. Food Quality and Preference 16:91-101.

Oreglia F, De Stefani E, Boffetta P, Brennan P, Deneo Pellegrini H. 2001. Meat, fat and risk of laryngeal cancer: a case-control study in Uruguay. Oral Oncology 37:141-145. 
Peters U, DeMarini DM, Sinha R, Brooks LR, Warren SH, Chatterjee N, Rothman N. 2003. Urinary mutagenicity and colorectal adenoma risk. Cancer Epidemiology, Biomarkers \& Prevention 12:1253-1256.

Pietinen P, Malila N, Virtanen M, Hartman TJ, Tangrea JA, Albanes D, Virtamo J. 1999. Diet and risk of colorectal cancer in a cohort of Finnish men. Cancer Causes \& Control 10:387-396.

Probsttensch NM, Sinha R, Longnecker MP, Witte JS, Ingles SA, Frankl HD, Lee ER, Haile RW. 1997. Meat preparation and colorectal adenomas in a large sigmoidoscopy-based case-control study in California (United States). Cancer Causes \& Control 8:175-183.

Sanz Alaejos M, Afonso AM. Content of heterocyclic aromatic amines in foods. Submitted for publication.

Sanz Alaejos M, Ayala JH, González V, Afonso AM. Analytical methods applied to the heterocyclic aromatic amines determination in foods. Submitted for publication a.

Sanz Alaejos M, Pino V, Afonso AM. Heterocyclic aromatic amines intake, genetic aspects and human cancer risk. Submitted for publication $b$.

Seow A, Poh WT, Teh M, Eng P, Wang YT, Tan WC, Yu MC, Lee HP. 2000. Fumes from meat cooking and lung cancer risk in Chinese women. Cancer Epidemiology, Biomarkers \& Prevention 9:1215-1221.

Shannon J, White E, Shattuck AL, Potter JD. 1996. Relationship of food groups and water intake to colon cancer risk. Cancer Epidemiology, Biomarkers \& Prevention 5:495-502.

Singh PN, Fraser GE. 1998. Dietary risk factors for colon cancer in a low-risk population. American Journal of Epidemiology 148:761-774.

Sinha R. 2002. An epidemiologic approach to studying heterocyclic amines. Mutation Research 506-507:197-204.

Sinha R, Chow WH, Kulldorff M, Denobile J, Butler J, García-Closas M, Weil R, Hoover RN, Rothman N. 1999. Well-done, grilled red meat increases the risk of colorectal adenomas. Cancer Research 59:4320-4324. 
Sinha R, Kulldorff M, Chow WH, Denobile J, Rothman N. 2001. Dietary intake of heterocyclic amines, meat-derived mutagenic activity, and the risk of colorectal adenomas. Cancer Epidemiology, Biomarkers \& Prevention 10:559-562.

Sinha R, Kulldorff M, Curtin J, Brown CC, Alavanja MCR, Swanson CA. 1998. Fried, well-done red meat and risk of lung cancer in women (United States). Cancer Causes \& Control 9:621-630.

Sinha R, Kulldorff M, Swanson CA, Curtin J, Brownson RC, Alavanja MCR. 2000. Dietary heterocyclic amines and the risk of lung cancer among Missouri women. Cancer Research 60:3753-3756.

Sinha R, Peters U, Cross AJ, Kulldorff M, Weissfeld JL, Pinsky PF, Rothman N, Hayes RB. 2005. Meat, meat cooking methods and preservation, and risk for colorectal adenoma. Cancer Research 65:8034-8041.

Sinha R, Rothman N. 1997. Exposure assessment of heterocyclic amines (HCAs) in epidemiologic studies. Mutation Research 376:195-202.

Sinha R, Rothman N. 1999. Role of well-done, grilled red meat, heterocyclic amines (HCAs) in the etiology of human cancer. Cancer Letters 143:189-194.

Sinha R, Rothman N, Mark SD, Murray S, Brown ED, Levander OA, Davies DS, Lang NP, Kadlubar FF, Hoover RN. 1995. Lower levels of urinary 2-amino-3,8-dimethylimidazo[4,5-f]-quinoxaline (MelQx) in humans with higher CYP1A2 activity. Carcinogenesis 16:2859-2861.

Skog K. 2002. Problems associated with the determination of heterocyclic amines in cooked foods and human exposure. Food and Chemical Toxicology 40:1197-1203.

Slattery ML, Berry TD, Potter J, Caan B. 1997. Diet diversity, diet composition, and risk of colon cancer (United States). Cancer Causes \& Control 8:872-882.

Stillwell WG, Kidd LCR, Wishnok JS, Tannenbaum SR, Sinha R. 1997. Urinary excretion of unmetabolized and phase II conjugates of 2-amino-1-methyl-6-phenylimidazo[4,5-b]pyridine and 2-amino-3,8-dimethylimidazo[4,5-f]quinoxaline in humans: relationship to cytochrome P4501A2 and N-acetyltransferase activity. Cancer Research 57:3457-3464. 
Stillwell WG, Turesky RJ, Gross GA, Skipper PL, Tannenbaum SR. 1994. Human urinary excretion of sulfamate and glucuronide conjugates of 2-amino-3,8-dimethylimidazo[4,5-f]quinoxaline (MelQx). Cancer Epidemiology, Biomarkers \& Prevention 3:399-405.

Stillwell WG, Turesky RJ, Sinha R, Skipper PL, Tannenbaum SR. 1999a. Biomonitoring of heterocyclic aromatic amines in human urine. Cancer Letters 143:145-148.

Stillwell WG, Turesky RJ, Sinha R, Tannenbaum SR. 1999b. N-oxidative metabolism of 2-amino3,8-dimethylimidazo[4,5-f]quinoxaline (MeIQx) in humans: excretion of the N-2-glucuronide conjugate of 2-hydroxyamino-MelQx in urine. Cancer Research 59:5154-5159.

Strickland PT, Qian Z, Friesen MD, Rothman N, Sinha R. 2001. Measurement of 2-amino-1-methyl6-phenylimidazo[4,5b]pyridine (PhIP) in acid-hydrolyzed urine by high-performance liquid chromatography with fluorescence detection. Biomarkers 6:313-325.

Sugimura T, Nagao M, Wakabayashi K. 1996. Carcinogenicity of food mutagens. Environmental Health Perspectives 104:429-433.

Tavani A, La Vecchia C, Gallus S, Lagiou P, Trichopoulos D, Levi F, Negri E. 2000. Red meat intake and cancer risk: a study in Italy. International Journal of Cancer 86:425-428.

Terry PD, Lagergren J, Wolk A, Steineck G, Nyren O. 2003. Dietary intake of heterocyclic amines and cancers of the oesophagus and gastric cardia. Cancer Epidemiology, Biomarkers \& Prevention 12:940-944.

Tiemersma EW, Kampman E, de Mesquita HBB, Bunschoten A, van Schothorst EM, Kok FJ, Kromhout D. 2002. Meat consumption, cigarette smoking, and genetic susceptibility in the ethiology of colorectal cancer: results from a Dutch prospective study. Cancer Causes \& Control 13:383-393.

Tiemersma EW, Voskuil DW, Bunschoten A, Hogendoorn EA, Witteman BJM, Nagengast FM, Glatt H, Kok FJ, Kampman E. 2004. Risk of colorectal adenomas in relation to meat consumption, meat preparation, and genetic susceptibility in a Dutch population. Cancer Causes \& Control 15:225-236. 
Truswell AS. 2002. Meat consumption and cancer of the large bowel. European Journal of Clinical Nutrition 56:S19-S24.

Turesky RJ, Constable A, Fay LB, Guengerich FP. 1999. Interspecies differences in metabolism of heterocyclic amines by rat and human P450 1A2. Cancer Letters 143:109-112.

Turesky RJ, Garner RC, Welti DH, Richoz J, Leveson SH, Dingley KH, Turteltaub KW, Fay LB. 1998. Metabolism of the food-borne mutagen 2-amino-3,8-dimethylimidazo[4,5-f]quinoxaline (MelQx) in humans. Chemical Research in Toxicology 11:217-225.

Turesky RJ, Parisod V, Huynh-Ba T, Langouët S, Guengerich FP. 2001. Regioselective differences in $\mathrm{C} 8$ and $\mathrm{N}$-oxidation of 2-amino-3,8-dimethylimidazo[4,5-f]quinoxaline by human and rat liver microsomes and cytochromes P450 1A2. Chemical Research in Toxicology 14:901-911.

Wakabayashi K, Totsuka Y, Fukutome K, Oguri A, Ushiyama H, Sugimura T. 1997. Human exposure to mutagenic/carcinogenic heterocyclic amines and co-mutagenic $\beta$-carbolines. Mutation Research 376:253-259.

Ward MH, Sinha R, Heineman EF, Rothman N, Markin R, Weisenburger DD, Correa P, Zahm SH. 1997. Risk of adenocarcinoma of the stomach and oesophagus with meat cooking method and doneness preference. International Journal of Cancer 71:14-19.

WCRF/AICR. 1997. In: Food, Nutrition and the Prevention of Cancer: A Global Perspective. World Cancer Research Fund and the American Institute for Cancer Research. Washington, DC.

Wild CP, Andersson C, O'Brien NM, Wilson L, Woods JA. 2001. A critical evaluation of the application of biomarkers in epidemiological studies on diet and health. British Journal of Nutrition 86:S37-S53.

Zhang SM, Hunter DJ, Rosner BA, Colditz GA, Fuchs CS, Speizer FE, Willett WC. 1999. Dietary fat and protein in relation to risk of non-Hodgkin's lymphoma among women. Journal of the National Cancer Institute 91:1751-1758.

Zheng W, Gustafson DR, Sinha R, Cerham JR, Moore D, Hong CP, Anderson KE, Kushi LH, Sellers TA, Folsom AR. 1998. Well-done meat intake and the risk of breast cancer. Journal of the National Cancer Institute 90:1724-1729. 
1

2

3

4

5

6

7

8

9

10

11

12

13

14

15

16

17

18

19

20

21

22

23

24

25

26

27

28

29

30

31

32

33

34

35

36

37

38

39

40

41

42

43

44

45

46

47

48

49

50

51

52

53

54

55

56

57

58

59

60

Zimmerli B, Rhyn P, Zoller O, Schlatter J. 2001. Occurrence of heterocyclic aromatic amines in the Swiss diet: analytical method, exposure estimation and risk assessment. Food Additives \& Contaminants 18:533-551. 
Table I. Classification of HAAs

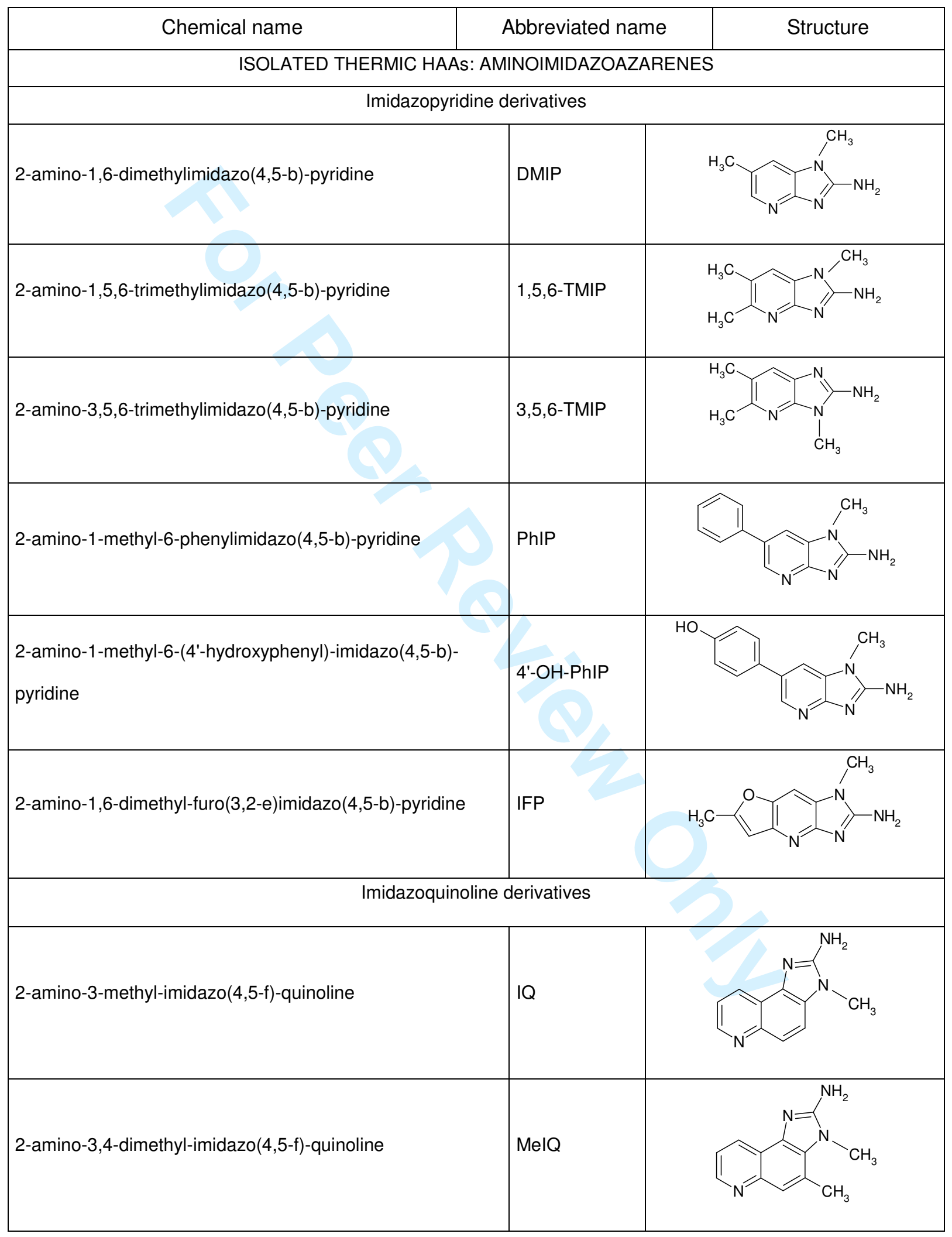




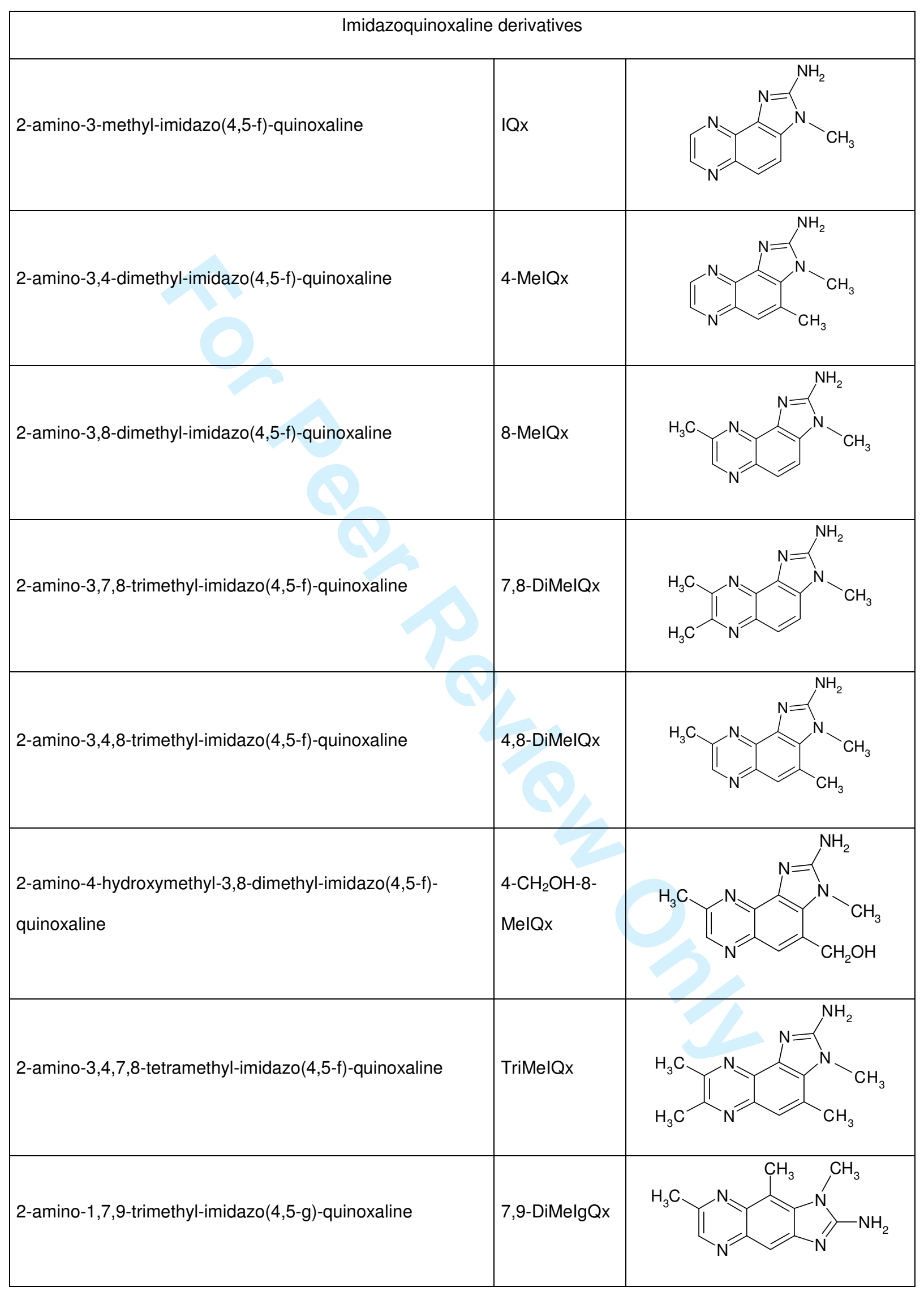




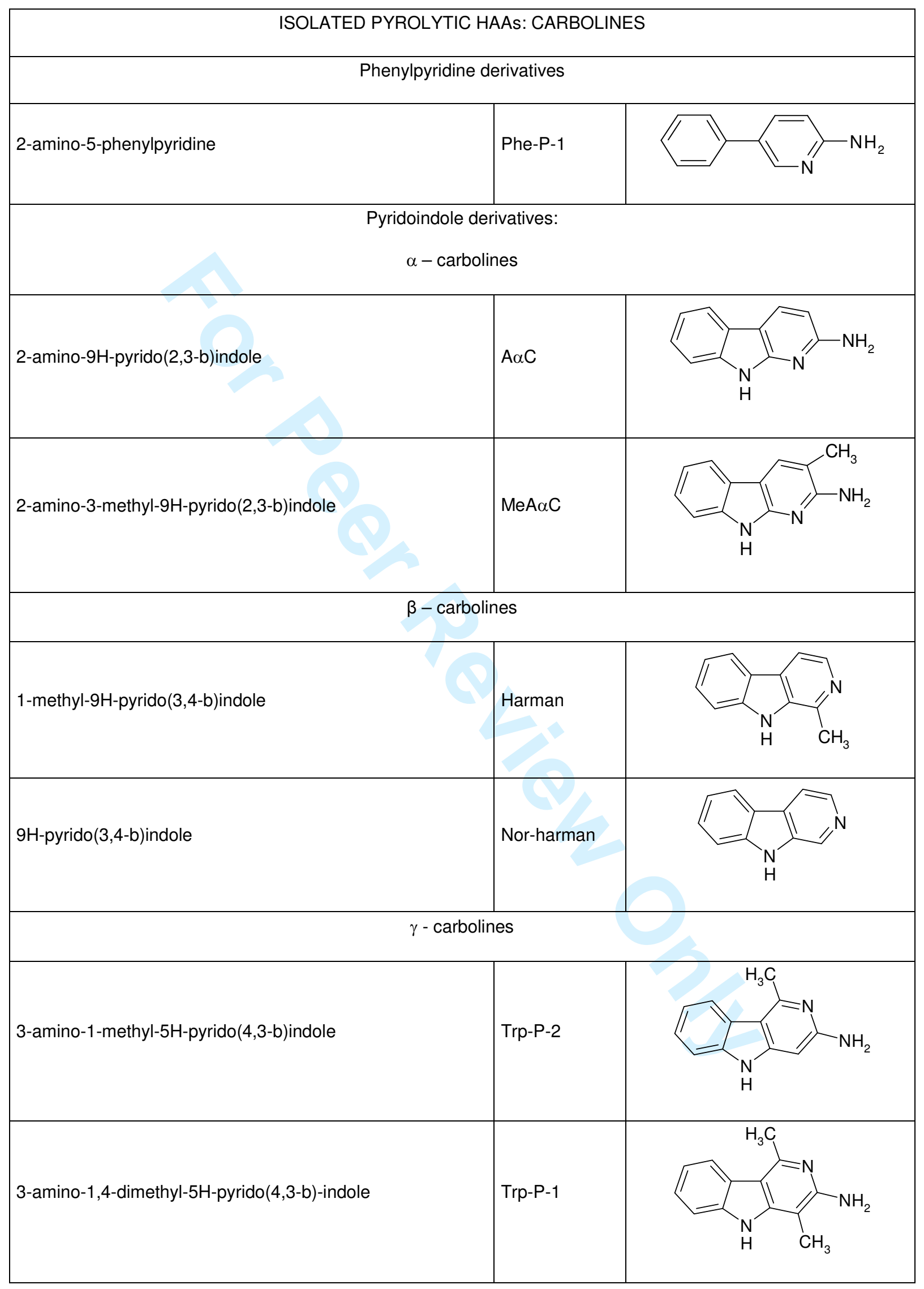




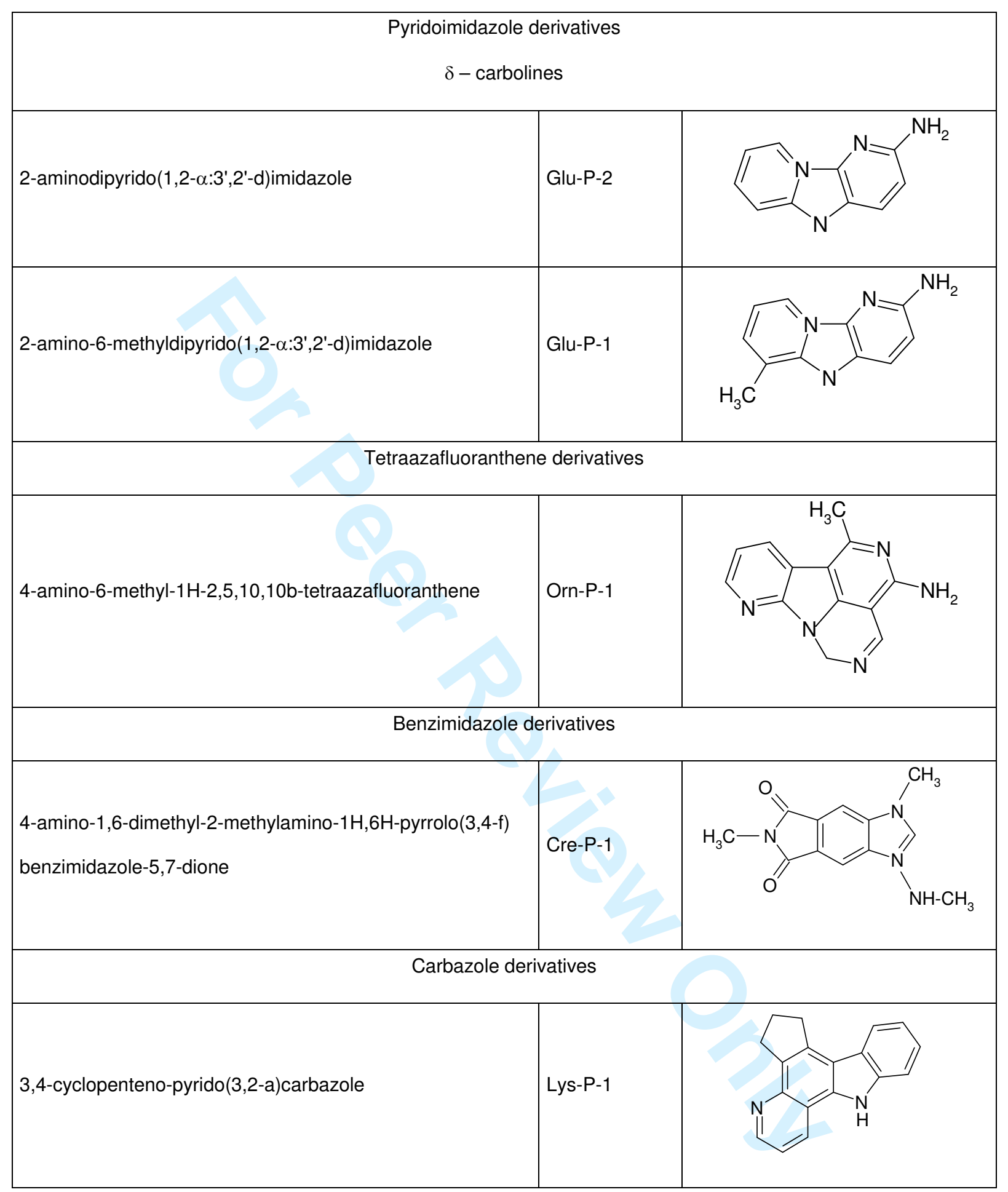


Table II. Influence of HAAs consumption on cancer risk development

\begin{tabular}{|c|c|c|c|c|c|c|c|}
\hline Cancer sites & Cases & Controls & \begin{tabular}{|l|} 
Odds \\
ratios
\end{tabular} & $\begin{array}{c}95 \% \text { confidence } \\
\text { interval }\end{array}$ & Intakes (observations) & $\begin{array}{c}\text { Geographical } \\
\text { location }\end{array}$ & Ref. \\
\hline \multirow[t]{3}{*}{ Aero-digestive } & \multirow[t]{3}{*}{140} & \multirow[t]{3}{*}{286} & \multicolumn{2}{|c|}{ Non significant } & Fried meat, white meat & \multirow[t]{3}{*}{ Uruguay } & \multirow{3}{*}{$\begin{array}{c}\text { De Stefani et al. } \\
1998\end{array}$} \\
\hline & & & 2.0 & $1.0-4.3$ & Broiled meat & & \\
\hline & & & 2.8 & $1.4-6.0$ & Red meat & & \\
\hline \multirow[t]{5}{*}{ Bladder } & \multirow[t]{2}{*}{273} & \multirow[t]{2}{*}{553} & 0.8 & $0.5-1.5$ & Total meat and fish & \multirow[t]{2}{*}{ Sweden } & \multirow{2}{*}{$\begin{array}{c}\text { Augustsson et } \\
\text { al. } 1999\end{array}$} \\
\hline & & & 1.2 & $0.7-2.1$ & HAAs or PhIP & & \\
\hline & \multirow[t]{3}{*}{144} & \multirow[t]{3}{*}{576} & \multicolumn{2}{|c|}{ Non significant } & Well-done fried meat & \multirow[t]{3}{*}{ Uruguay } & \multirow[t]{3}{*}{ Balbi et al. 2001} \\
\hline & & & 0.38 & $0.23-0.64$ & Fruits, cooked vegetables, potatoes, cheese & & \\
\hline & & & 4.04 & $2.24-7.27$ & Barbecued meat, salted meat, fried eggs, $\mathrm{N}$-nitroso compounds & & \\
\hline \multirow[t]{2}{*}{ Breast } & \multirow[t]{2}{*}{352} & \multirow[t]{2}{*}{382} & 3.34 & $1.85-6.02$ & For IQ, in red meat, total meat, beef, fried meat (OR: 2.6 for PhIP) & \multirow[t]{2}{*}{ Uruguay } & \multirow{2}{*}{$\begin{array}{c}\text { De Stefani et al. } \\
1997\end{array}$} \\
\hline & & & 5.3 & $2.8-10.2$ & Fried red meat & & \\
\hline
\end{tabular}




\begin{tabular}{|c|c|c|c|c|c|c|c|}
\hline & \multirow[t]{4}{*}{273} & \multirow[t]{4}{*}{657} & 1.54 & $0.96-2.47$ & Very well-done hamburger & \multirow[t]{4}{*}{ USA (lowa) } & \multirow{4}{*}{$\begin{array}{c}\text { Zheng et al. } \\
1998\end{array}$} \\
\hline & & & 1.64 & $0.92-2.93$ & Very well-done bacon & & \\
\hline & & & 2.21 & $1.30-3.77$ & Very well-done beef steaks & & \\
\hline & & & 4.64 & $1.36-15.70$ & Very well-done meats & & \\
\hline \multirow[t]{10}{*}{ Colon } & \multirow[t]{3}{*}{352} & \multirow[t]{3}{*}{553} & 0.6 & $0.4-1.0$ & HAAs & \multirow[t]{3}{*}{ Sweden } & \multirow{3}{*}{$\begin{array}{c}\text { Augustsson et } \\
\text { al. } 1999\end{array}$} \\
\hline & & & 0.9 & $0.5-1.4$ & Total meat and fish & & \\
\hline & & & 1.0 & $0.7-1.4$ & (current smoking) & & \\
\hline & \multirow[t]{3}{*}{1542} & \multirow[t]{3}{*}{1860} & 0.9 & & Red and white meat & \multirow[t]{3}{*}{ USA } & \multirow{3}{*}{$\begin{array}{c}\text { Kampman et al. } \\
1999\end{array}$} \\
\hline & & & 1.2 & $0.9-1.5$ & Well-done red meat & & \\
\hline & & & 1.4 & $1.0-1.9$ & Processed meat (men) & & \\
\hline & \multirow[t]{4}{*}{2474} & \multirow[t]{4}{*}{34817} & 1.11 & $0.97-1.27$ & DiMelQx; red meat (processed, roasted) & \multirow[t]{4}{*}{ USA } & \multirow[t]{4}{*}{ Sinha et al. 2005} \\
\hline & & & 1.17 & $1.01-1.35$ & PhlP; red meat (processed, roasted) & & \\
\hline & & & 1.18 & $1.01-1.38$ & MelQx; red meat (processed, roasted) & & \\
\hline & & & 1.18 & $1.02-1.35$ & Benzo\{a\}pyrene; red meat (processed, roasted) & & \\
\hline
\end{tabular}




\begin{tabular}{|c|c|c|c|c|c|c|c|}
\hline & 513 & 513 & 0.8 & $0.5-1.2$ & Grilled/barbecued meat and fish & USA (Hawaii) & LeMarchand et \\
\hline & & & 0.9 & $0.6-1.3$ & Well-done meat and fish & & al. 2002 \\
\hline & & & 1.0 & $0.7-1.5$ & Total red meat; red meat, well- or very well-done & & \\
\hline & & & 1.3 & $0.8-1.9$ & Pan-fried/oven broiled meat and fish & & \\
\hline & 289 & 289 & 1.0 & $0.6-1.1$ & MelQx (men) & & \\
\hline & & & 1.0 & $0.6-1.6$ & $\mathrm{PhIP}$ (men) & & \\
\hline & & & 1.1 & $0.7-1.7$ & 4,8-DiMelQx (men) & & \\
\hline & 620 & 1038 & 1.7 & $1.2-2.5$ & Well-, very well-done red meat & USA (North & Butler et al. 2003 \\
\hline & & & $1.8-2.0$ & & 4,8-DiMelQx & Caroline) & \\
\hline & & & 2.0 & $1.3-3.2$ & Red meat, pan-fried red meat & & \\
\hline Colorectal & 88 & 200 & 0.74 & $0.52-1.05$ & Boiling/stewing white meat, $>21.6 \mathrm{~g} /$ day & Argentina & Navarro et al. \\
\hline & 87 & 200 & 0.93 & $0.65-1.34$ & Boiling/stewing red meat, $>31.2 \mathrm{~g} /$ day & (Córdoba) & 2004 \\
\hline & 110 & 199 & 1.08 & $0.76-1.54$ & Roasted red meat, darkly browned & & \\
\hline & 148 & & 2.19 & $1.53-3.12$ & Roasted white meat, darkly browned & & \\
\hline & 128 & & 1.42 & $1.00-2.02$ & Fried white meat, darkly browned & & \\
\hline
\end{tabular}




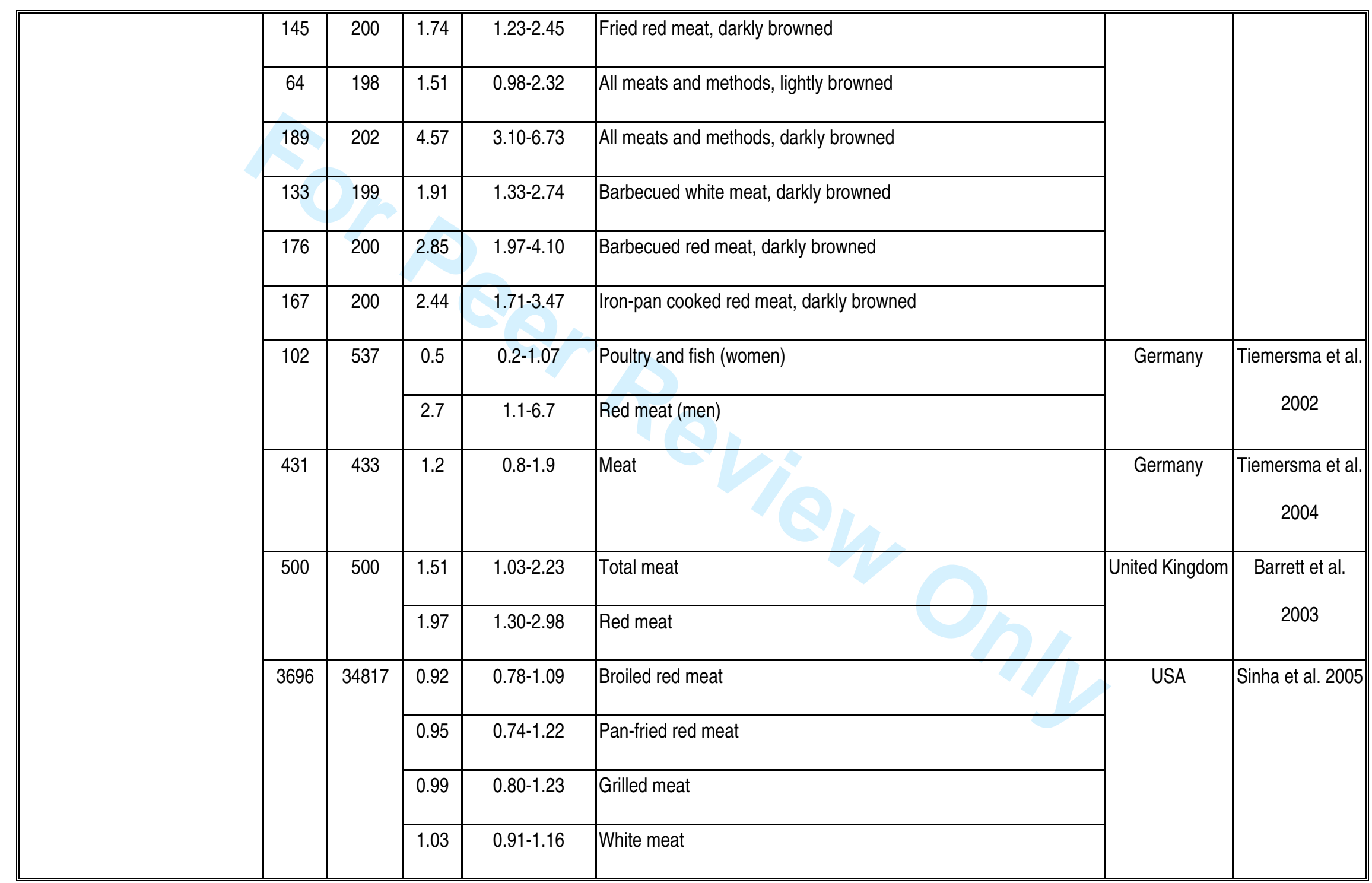




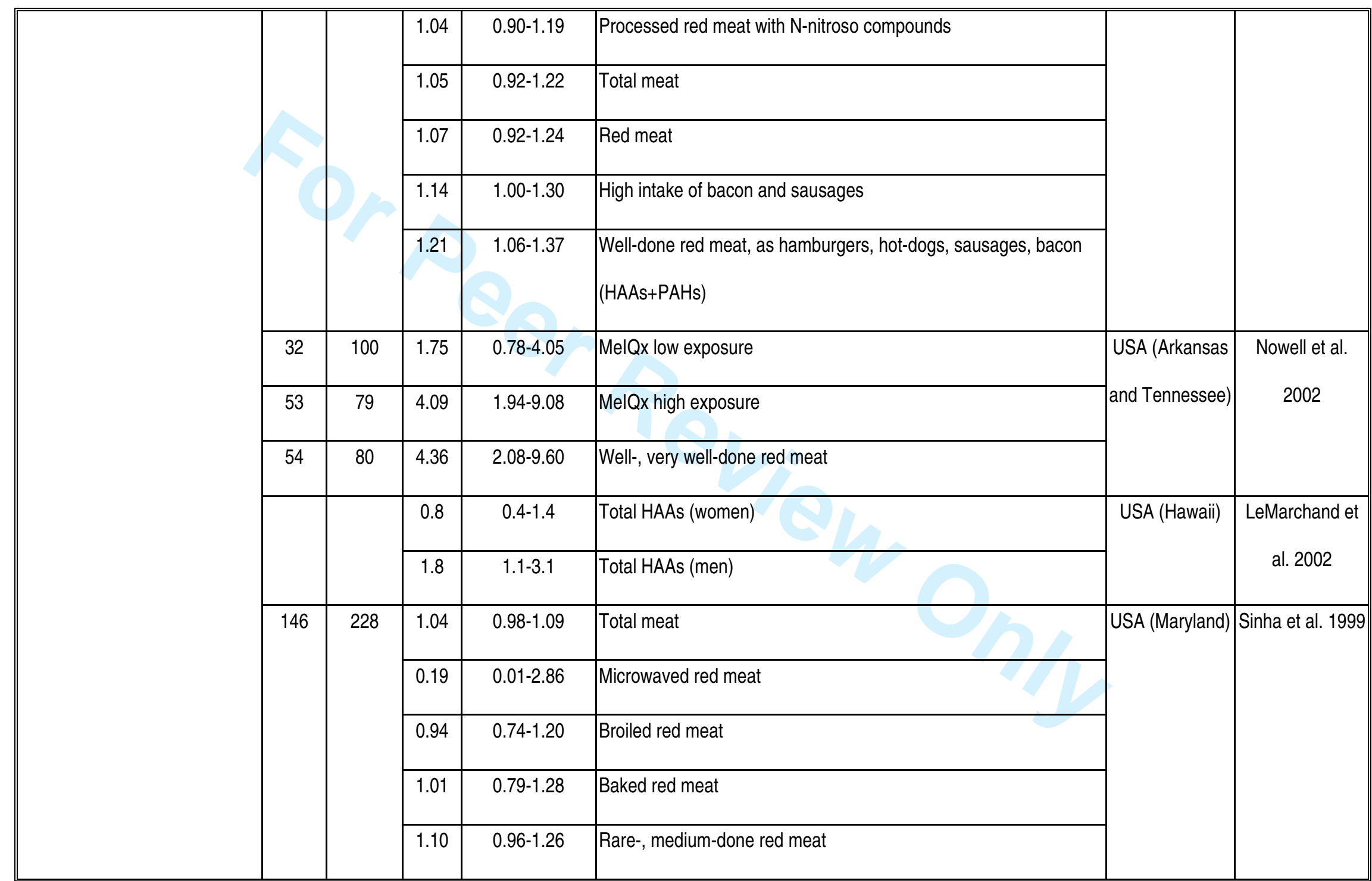




\begin{tabular}{|c|c|c|c|c|c|c|c|}
\hline & & & 2.11 & $0.90-4.92$ & Very well-done red meat & & \\
\hline & & & 1.15 & $0.97-1.36$ & Pan-fried red meat & & \\
\hline & & & 1.22 & $0.92-1.61$ & Well-, very well-done pan-fried red meat & & \\
\hline & & & 1.26 & $1.06-1.50$ & Grilled/barbecued red meat & & \\
\hline & & & 1.85 & $1.24-2.75$ & Well-, very well-done grilled/barbecued red meat & & \\
\hline & 146 & 228 & 1.11 & $1.03-1.19$ & Red meat & USA (Maryland, & Sinha et al. \\
\hline & & & 1.29 & $1.08-1.54$ & Well-, very well-done red meat & Missouri) & 1999, 2001 \\
\hline & 146 & 228 & 2.1 & $1.0-4.3$ & MelQx & USA (Missouri) & Sinha et al. 2001 \\
\hline & & & 2.2 & $1.2-4.1$ & 4,8-DiMelQx & & \\
\hline & & & 2.5 & $1.1-5.5$ & 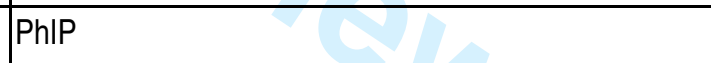 & & \\
\hline & & & 3.1 & $1.4-6.8$ & HAAs & & \\
\hline Colorectal adenomas & 488 & 488 & 2.2 & $1.1-4.3$ & Fried red meat, darkly browned (high frequent intake) & USA (California) & \begin{tabular}{|c} 
Probsttensch et \\
al. 1997
\end{tabular} \\
\hline & 565 & 565 & & significant & Well-done red meat (HAAs) & $\begin{array}{c}\text { USA (California, } \\
\text { southern) }\end{array}$ & $\begin{array}{l}\text { Gunter et al. } \\
2005\end{array}$ \\
\hline
\end{tabular}




\begin{tabular}{|c|c|c|c|c|c|c|c|}
\hline Esophagus (squamous cell) & 150 & \multirow[t]{3}{*}{745} & 2.4 & $\begin{array}{c}1.2-4.8 \\
\end{array}$ & \multirow{3}{*}{$\begin{array}{l}\text { Fried meats, pan juices } \\
\text { High intake of MelQx, 4,8-DiMelQx, and PhIP }\end{array}$} & \multirow[t]{3}{*}{ Sweden } & \multirow[t]{3}{*}{ Terry et al. 2003} \\
\hline Esophagus (adenocarcinoma) & 157 & & 0.7 & $0.4-1.2$ & & & \\
\hline $\begin{array}{l}\text { Gastric cardia } \\
\text { (adenocarcinoma) }\end{array}$ & 233 & & 1.3 & $0.8-2.1$ & & & \\
\hline \multirow[t]{6}{*}{ Kidney } & \multirow[t]{2}{*}{138} & \multirow[t]{2}{*}{553} & 1.0 & $0.5-1.9$ & HAAs or total meat and fish & \multirow[t]{2}{*}{ Sweden } & \multirow{2}{*}{$\begin{array}{c}\text { Augustsson et } \\
\text { al. } 1999\end{array}$} \\
\hline & & & 1.3 & $0.8-2.1$ & (Current smoking) & & \\
\hline & \multirow[t]{4}{*}{121} & \multirow[t]{4}{*}{243} & 0.78 & $0.45-1.39$ & Processed meat & \multirow[t]{4}{*}{ Uruguay } & \multirow{4}{*}{$\begin{array}{l}\text { De Stefani et al. } \\
\qquad 1998\end{array}$} \\
\hline & & & 2.07 & $1.03-4.19$ & High intake of barbecued meat & & \\
\hline & & & 2.18 & $1.14-4.19$ & $\operatorname{PhIP}(>15.6 \mathrm{ng} / \mathrm{d})$ & & \\
\hline & & & 3.42 & $1.76-6.65$ & High intake of red meat & & \\
\hline \multirow[t]{5}{*}{ Lung } & \multirow[t]{5}{*}{303} & \multirow[t]{5}{*}{765} & 1.0 & $0.5-2.4$ & Stir-fried meat less often than daily (smokers, women) & \multirow[t]{5}{*}{ China } & \multirow[t]{5}{*}{ Seow et al. 2000} \\
\hline & & & 2.7 & $1.3-5.5$ & Stir-fried meat daily (smokers, women) & & \\
\hline & & & 3.7 & $1.8-7.5$ & $\begin{array}{l}\text { Stir-fried meat daily (kitchen fined with oily fumes during cooking, } \\
\text { women) }\end{array}$ & & \\
\hline & & & 4.3 & $2.7-6.8$ & Fumes from meat cooking (ex-smokers, women) & & \\
\hline & & & 5.0 & $3.4-7.3$ & Fumes from meat cooking (current smokers, women) & & \\
\hline
\end{tabular}




\begin{tabular}{|c|c|c|c|c|c|c|c|}
\hline & 256 & 284 & & ignificant & Red meat, fried meat & Uruguay & Deneo Pellegrini \\
\hline & 593 & 623 & 1.5 & $1.1-2.1$ & Fried or well-done red meat (women) & USA (Missouri) & Sinha et al. 1998 \\
\hline & & & 1.6 & $1.1-2.4$ & Total meat (women) & & \\
\hline & & & 1.8 & $1.2-2.7$ & Red meat (women) & & \\
\hline & 593 & 623 & 1.3 & $0.9-1.9$ & Fried or well-done red meat (women) & USA (Missouri) & Sinha et al. 2000 \\
\hline & & & 1.4 & $1.0-1.9$ & Total meat or red meat (women) & & \\
\hline & & & 1.5 & $1.1-2.0$ & Barbecued red meat or smoked meat (women) & & \\
\hline & & & 0.9 & $0.8-1.1$ & PhIP (women) & & \\
\hline & & & 1.2 & $0.9-1.6$ & DiMelQx (women) & & \\
\hline & & & 1.5 & $1.1-2.0$ & MelQx (women) & & \\
\hline & 343 & 200 & 1.0 & $0.7-1.5$ & MelQx (women, heavy smokers) & & \\
\hline & 203 & 340 & 2.1 & $1.3-3.3$ & MelQx (women, light/moderate smokers) & & \\
\hline & 47 & 83 & 3.6 & $1.3-10.3$ & MelQx (women, non smokers) & & \\
\hline Lung, squamous cell carcinoma & & & 1.9 & $1.2-3.1$ & MelQx (women) & & \\
\hline Lung, other histological types & & & 1.6 & $1.1-2.5$ & MelQx (women) & & \\
\hline
\end{tabular}




\begin{tabular}{|c|c|c|c|c|c|c|c|}
\hline \multirow[t]{5}{*}{ Pancreas (exocrine) } & \multirow[t]{5}{*}{193} & \multirow[t]{5}{*}{674} & 1.5 & $0.9-2.7$ & MelQx; well-done barbecued meat and pan-fried meat & \multirow[t]{5}{*}{ USA } & \multirow{5}{*}{$\begin{array}{l}\text { Anderson et al. } \\
\qquad 2005\end{array}$} \\
\hline & & & 1.8 & $1.0-3.1$ & PhIP; well-done barbecued meat and pan-fried meat & & \\
\hline & & & 2.0 & $1.2-3.5$ & DiMelQx; well-done barbecued meat and pan-fried meat & & \\
\hline & & & 2.2 & $1.2-4.0$ & Benzo\{a\}pyrene; well-done barbecued meat and pan-fried meat & & \\
\hline & & & 2.4 & $1.3-4.3$ & Mutagenic activity; well-done barbecued meat and pan-fried meat & & \\
\hline \multirow[t]{3}{*}{ Pancreas } & \multirow[t]{3}{*}{193} & \multirow[t]{3}{*}{674} & 0.7 & $0.4-1.2$ & Broiled red meat & \multirow{3}{*}{$\begin{array}{l}\text { USA (upper } \\
\text { Midwest area) }\end{array}$} & \multirow{3}{*}{$\begin{array}{c}\text { Anderson et al. } \\
2002\end{array}$} \\
\hline & & & 1.4 & $0.7-2.6$ & Fried red meat & & \\
\hline & & & 2.2 & 1.4-3.4 & Grilled/barbecued red meat & & \\
\hline \multirow[t]{4}{*}{ Prostate } & \multirow[t]{3}{*}{317} & \multirow[t]{3}{*}{480} & \multicolumn{2}{|c|}{ Non significant } & Meat doneness and major HAAs & \multirow[t]{3}{*}{ New Zealand } & \multirow{3}{*}{$\begin{array}{c}\text { Norrish et al. } \\
1999\end{array}$} \\
\hline & & & \multicolumn{2}{|c|}{ Weakly significant } & IFP & & \\
\hline & & & 1.68 & $1.02-2.77$ & Very well-done beef steaks & & \\
\hline & 464 & 459 & 1.68 & $1.20-2.36$ & Well-done meat & USA & $\begin{array}{l}\text { Nowell et al. } \\
2004\end{array}$ \\
\hline \multirow[t]{3}{*}{ Rectum } & \multirow[t]{3}{*}{249} & \multirow[t]{3}{*}{553} & 0.7 & $0.4-1.1$ & HAAs & \multirow[t]{3}{*}{ Sweden } & \multirow{3}{*}{$\begin{array}{c}\text { Augustsson et } \\
\text { al. } 1999\end{array}$} \\
\hline & & & 1.0 & $0.6-1.6$ & Total meat and fish & & \\
\hline & & & 0.9 & $0.6-1.4$ & (Current smoking) & & \\
\hline
\end{tabular}




\begin{tabular}{|c|c|c|c|c|c|c|c|}
\hline & 688 & 34817 & \multicolumn{2}{|c|}{ Non significant } & PhIP, MelQx, DiMelQx, benzo\{a\}pyrene & USA & Sinha et al. 2005 \\
\hline & \multirow[t]{2}{*}{952} & \multirow[t]{2}{*}{1205} & 1.33 & $0.98-1.79$ & Well-done red meat (men) & \multirow{2}{*}{$\begin{array}{c}\text { USA (California } \\
\text { and Utah) }\end{array}$} & \multirow{2}{*}{$\begin{array}{l}\text { Murtaugh et al. } \\
\qquad 2004\end{array}$} \\
\hline & & & 1.37 & $0.98-1.92$ & Mutagen index (men) & & \\
\hline & \multirow[t]{5}{*}{210} & \multirow[t]{5}{*}{210} & 0.8 & $0.4-1.6$ & Oven broiled, grilled/barbecued meat and fish & \multirow[t]{8}{*}{ USA (Hawaii) } & \multirow{8}{*}{$\begin{array}{c}\text { LeMarchand et } \\
\text { al. } 2002\end{array}$} \\
\hline & & & 1.2 & $0.7-2.0$ & Well-done meat and fish & & \\
\hline & & & 1.5 & $0.9-2.4$ & Well-, very well-done red meat & & \\
\hline & & & 1.6 & $1.0-2.5$ & Pan-fried meat and fish & & \\
\hline & & & 1.7 & $1.0-3.0$ & Total red meat & & \\
\hline & \multirow[t]{3}{*}{137} & \multirow[t]{3}{*}{137} & 1.7 & $0.3-3.8$ & PhIP (men) & & \\
\hline & & & 2.7 & $1.1-6.3$ & 4,8-DiMelQx (men) & & \\
\hline & & & 3.1 & $1.3-7.7$ & MelQx (men) & & \\
\hline \multirow[t]{4}{*}{ Stomach } & \multirow[t]{4}{*}{123} & \multirow[t]{4}{*}{282} & 1.7 & $0.7-4.0$ & Total meat and proteins, total energy and total fat & \multirow[t]{4}{*}{ Uruguay } & \multirow{4}{*}{$\begin{array}{c}\text { De Stefani et al. } \\
2001\end{array}$} \\
\hline & & & 1.9 & $1.1-3.5$ & Energy adjusted for high intake of processed meat & & \\
\hline & & & 4.6 & $2.3-9.0$ & Total meat & & \\
\hline & & & \multicolumn{2}{|c|}{ Non significant } & Fried, barbecued, salted meat and PhIP & & \\
\hline
\end{tabular}


Table III. Influence of foods/nutrients intake on cancer risk development

\begin{tabular}{|c|c|c|c|c|c|}
\hline Cancer sites & Higher risk (odds ratio) & Protective effect (odds ratio) & No association (odds ratio) & $\begin{array}{l}\text { Geographical } \\
\text { location }\end{array}$ & Ref. \\
\hline Bladder & Red meat (1.6) & & & Italy (Northern) & $\begin{array}{c}\text { Tavani et al. } \\
2000\end{array}$ \\
\hline Brain & Salted vegetables, salted fish & $\begin{array}{l}\text { Vegetables, fruit, fresh fish, poultry, } \mathrm{Ca} \text {, } \\
\text { vitamins } \mathrm{E}, \mathrm{C}, \beta \text {-carotene }\end{array}$ & & China (Northeast) & Hu et al. 1999 \\
\hline \multirow[t]{2}{*}{ Breast } & $\begin{array}{l}\text { Well-done deep-fried red meat (1.92), } \\
\text { freshwater fish }\end{array}$ & Non-hydrogenated soybean oil $(0.48)$ & 4 & China (Shanghai) & Dai et al. 2002 \\
\hline & Red meat (1.2) & & 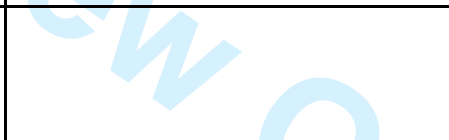 & Italy (Northern) & $\begin{array}{c}\text { Tavani et al. } \\
2000\end{array}$ \\
\hline \multirow[t]{2}{*}{ Colon } & $\begin{array}{l}\text { High intake of preserved animal or } \\
\text { vegetal foods (men: 2.0; women: } 2.7 \text { ), } \\
\text { eggs (1.3), fish (men: 1.7), red meat } \\
(1.5)\end{array}$ & $\begin{array}{l}\text { Fresh fruit (0.6), vitamins } E, C, \beta \text { - } \\
\text { carotene, fiber }\end{array}$ & Fish (women: 1.2) & China (Shanghai) & Chiu et al. 2003 \\
\hline & Fresh red meat (women: 2.35), high & Vegetables (0.4) & Fresh red meat (men: 0.89) & Germany & Kampman et al. \\
\hline
\end{tabular}

http://mc.manuscriptcentral.com/tfac Email: fac@tandf.co.uk 


\begin{tabular}{|c|c|c|c|c|}
\hline $\begin{array}{l}\text { consumption of red meat and low } \\
\text { consumption of vegetables and fruits } \\
\text { (women: 3.1) }\end{array}$ & & & & 1995 \\
\hline Red meat (1.9) & & & Italy (Northern) & $\begin{array}{l}\text { Tavani et al. } \\
2000\end{array}$ \\
\hline Sausages (women 3.5) & 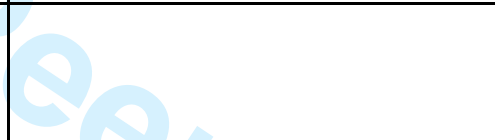 & $\begin{array}{l}\text { Meat, meat stews, roasted meat, fish, } \\
\text { milk, fat, energy, fiber, Ca }\end{array}$ & Norway & Gaard et al. 1996 \\
\hline $\begin{array}{l}\text { For distal colon: High intake ( } \geq 94 \mathrm{~g} \text { ) of } \\
\text { red meat, (women, prospective study: } \\
2.22 \text { ) }\end{array}$ & Poultry & $\begin{array}{l}\text { Broiled red meat (1.03), fish. } \\
\text { For rectum or proximal colon: red meat }\end{array}$ & Sweden & $\begin{array}{l}\text { Larsson et al. } \\
2005\end{array}$ \\
\hline $\begin{array}{l}\text { For distal colon: Long-term } \\
\text { consumption of red meat (1.53), or } \\
\text { processed meat (1.50) }\end{array}$ & Poultry, fish & $a_{3}$ & USA & Chao et al. 2005 \\
\hline $\begin{array}{l}\text { Diverse diet with greater proportion of } \\
\text { meat, fish, poultry and eggs (men: } 1.5 \text { ); } \\
\text { or with greater proportion of refined } \\
\text { grain products (men: } 1.7 \text { ) }\end{array}$ & $\begin{array}{l}\text { Diverse diet with greater proportion of } \\
\text { fruits, vegetables or whole grains } \\
\text { (women: } 0.7 \text { ) }\end{array}$ & Diverse diet & $\begin{array}{l}\text { USA (California, } \\
\text { Minnesota, Utah) }\end{array}$ & $\begin{array}{c}\text { Slattery et al. } \\
1997\end{array}$ \\
\hline
\end{tabular}




\begin{tabular}{|c|c|c|c|c|c|}
\hline & For distal colon: total meat (men: 2.20) & $\begin{array}{l}\text { Vegetables and fruits (women: } 0.48 \text { ), } \\
\text { cereals (women: } 0.47 \text {; men: } 0.43 \text { ), dairy } \\
\text { products (women: } 0.40 \text { ), water (women: } \\
0.55 \text {; men: } 0.68 \text { ) }\end{array}$ & $\begin{array}{l}\text { Total meat (women: 0.94; men: 1.17), } \\
\text { red meat (women: 0.72; men: 1.48) }\end{array}$ & USA (Seattle) & $\begin{array}{c}\text { Shannon et al. } \\
1996\end{array}$ \\
\hline \multirow[t]{6}{*}{ Colorectal } & $\begin{array}{l}\text { Bovine viscera (1.73), cold } \\
\text { cuts/sausages (1.47) }\end{array}$ & Lean beef $(0.67)$ & $\begin{array}{l}\text { Red meat }(0.63) \text {, total meats }(0.70) \text {, } \\
\text { white meat }(0.73) \text {, }\end{array}$ & $\begin{array}{l}\text { Argentina } \\
\text { (Córdoba) }\end{array}$ & $\begin{array}{l}\text { Navarro et al. } \\
2003\end{array}$ \\
\hline & & 50 & $\begin{array}{l}\text { Red meat; fried or processed meats; } \\
\text { fruits, vegetables }\end{array}$ & Finland & $\begin{array}{c}\text { Pietinen et al. } \\
1999\end{array}$ \\
\hline & $\begin{array}{l}\text { Processed meat (2.4); offal (2.1); } \\
\text { refined cereal products (rice, pasta, } \\
\text { pastry), delicatessen, butter, pates (1.7) }\end{array}$ & & $\begin{array}{l}\text { Fish (1.5); fresh meat (1.2); eggs (1.1); } \\
\text { dairy products (1.0) }\end{array}$ & France (Burgundy) & $\begin{array}{c}\text { Boutron-Ruault } \\
\text { et al. } 1999\end{array}$ \\
\hline & $\begin{array}{l}\text { Bread/cereal (1.7); refined sugar (1.4); } \\
\text { potatoes (1.2); cakes/desserts (1.1) }\end{array}$ & Vegetables, fruit, fish & Meat (white, red or processed), eggs & Italy & $\begin{array}{c}\text { Franceschi et al. } \\
1997\end{array}$ \\
\hline & Red meat (1.6) & Vitamin C, $\beta$-carotene & Processed meat & Italy (Northern) & $\begin{array}{c}\text { La Vecchia et al. } \\
1996\end{array}$ \\
\hline & Red meat (1.03-2.22) & Poultry & Fish & Sweden & $\begin{array}{l}\text { Larsson et al. } \\
2005\end{array}$ \\
\hline
\end{tabular}




\begin{tabular}{|c|c|c|c|c|c|}
\hline & $\begin{array}{l}\text { Red meat (1.54); refined grain (1.32); } \\
\text { pork or processed meat (1.27) }\end{array}$ & $\begin{array}{l}\text { Vegetables, fruit, garlic, whole grain, } \\
\text { coffee }\end{array}$ & & \begin{tabular}{|l|} 
Switzerland \\
(Canton of Vaud)
\end{tabular} & Levi et al. 1999 \\
\hline & $\begin{array}{l}\text { White meat (3.29), red meat (1.90), total } \\
\text { meat (1.85) }\end{array}$ & Legume (0.53) & & $\begin{array}{l}\text { USA (California) } \\
\text { (Seventh Day } \\
\text { Adventist) }\end{array}$ & $\begin{array}{c}\text { Singh and Fraser } \\
1998\end{array}$ \\
\hline & & Protein & $\begin{array}{l}\text { Total calories, total fat, subclasses of } \\
\text { fat, carbohydrates, dietary fiber }\end{array}$ & $\begin{array}{l}\text { USA (Florida, New } \\
\text { York) }\end{array}$ & Kato et al. 1997 \\
\hline & $\begin{array}{l}\text { Eggs (men: } 2.7 \text {; women: } 2.3 \text { ), } \\
\text { processed meat (men: } 2.3 \text { ), red meat } \\
(1.6)\end{array}$ & Chicken without skin & $\begin{array}{l}\text { Fat-trimmed red meat, fish; total fat, } \\
\text { saturated fat, polyunsaturated fat }\end{array}$ & USA (Hawaii) & $\begin{array}{c}\text { LeMarchand et } \\
\text { al. } 1997\end{array}$ \\
\hline & $\begin{array}{l}\text { Well-/very well-done red meat (fried or } \\
\text { grilled/barbecued) }\end{array}$ & $\begin{array}{l}\text { Vegetables (0.7), fruit/fruit juice }(0.8) \text {, } \\
\text { microwaved red meat }(0.19)\end{array}$ & $\begin{array}{l}\text { Broiled red meat (0.94), total meat, red } \\
\text { meat, grilled/barbecued red meat } \\
\text { (rare/medium done), pan-fried red meat } \\
\text { (rare/medium done), fat, alcoholic } \\
\text { beverages }\end{array}$ & USA (Maryland) & $\begin{array}{c}\text { Zheng et al. } \\
1998\end{array}$ \\
\hline Endometrium & Red meat (1.5) & & & |taly (Northern) & Tavani et al. \\
\hline Esophagus & & & Red meat & & 2000 \\
\hline
\end{tabular}




\begin{tabular}{|c|c|c|c|c|c|}
\hline & Soups, butter & Vegetables, fruit, olive oil, pasta, poultry & & |taly (Northern) & $\begin{array}{l}\text { Bosetti et al. } \\
2000\end{array}$ \\
\hline & & & Fried foods (1.16) & Italy, Switzerland & $\begin{array}{c}\text { Galeone et al. } \\
2005\end{array}$ \\
\hline & $\begin{array}{l}\text { Pan-fried red or processed meat; pan } \\
\text { juices }\end{array}$ & Barbecued meat, vitamin C, fiber & Total meat, red meat, white meat, fish & Sweden & Terry et al. 2003 \\
\hline & Red meat, barbecued/grilled & 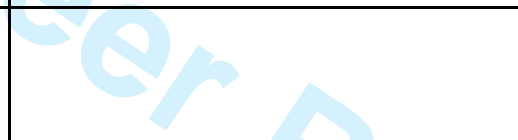 & $\begin{array}{l}\text { Doneness level; beef, chicken, or pork } \\
\text { (broiled or fried) }\end{array}$ & USA (Nebraska) & Ward et al. 1997 \\
\hline Gall bladder & & & Red meat & |taly (Northern) & Tavani et al. \\
\hline Gastric & Red meat (1.6) & 7 & 8 & & 2000 \\
\hline & Processed meat, bacon & $\begin{array}{l}\text { Vegetables (vitamins E, C, } \beta \text {-carotene, } \\
\text { folate) }\end{array}$ & $\begin{array}{l}\text { Vegetables with processed meat, or } \\
\text { with bacon }\end{array}$ & USA (Hawaii) & $\begin{array}{c}\text { Nomura et al. } \\
2003\end{array}$ \\
\hline & $\begin{array}{l}\text { Barbecued/grilling well-done meat (3.2), } \\
\text { red meat }\end{array}$ & & Beef, chicken or pork (broiled or fried) & USA (Nebraska) & Ward et al. 1997 \\
\hline Kidney & & & Red meat & Italy (Northern) & $\begin{array}{l}\text { Tavani et al. } \\
2000\end{array}$ \\
\hline & 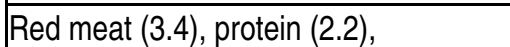 & Vegetables $(0.5)$ & Salted meat, processed meat, milk & Uruguay & De Stefani et al. \\
\hline
\end{tabular}




\begin{tabular}{|c|c|c|c|c|c|}
\hline & barbecued meat (2.1), fruits (1.7) & & & & $1998 \mathrm{a}$ \\
\hline \multirow[t]{3}{*}{ Larynx } & & & Red meat & Italy (Northern) & $\begin{array}{c}\text { Tavani et al. } \\
2000\end{array}$ \\
\hline & $\begin{array}{l}\text { Red meat or fried fish (3.1), fried eggs } \\
\text { or fried potatoes (1.9), processed meat } \\
\text { (1.7), fried meat (1.6) }\end{array}$ & Vegetables, fruit, olive oil & & $\begin{array}{l}\text { Italy (Northern), } \\
\text { Switzerland } \\
\text { (Canton of Vaud) }\end{array}$ & $\begin{array}{l}\text { Bosetti et al. } \\
2002 a, b\end{array}$ \\
\hline & $\begin{array}{l}\text { Total fat from red meat (7.05), red and } \\
\text { total meat (3.32) }\end{array}$ & $\sigma_{0}$ & & Uruguay & $\begin{array}{l}\text { Oreglia et al } \\
2001\end{array}$ \\
\hline Liver & & & Red meat & Italy (Northern) & $\begin{array}{l}\text { Tavani et al. } \\
2000\end{array}$ \\
\hline \begin{tabular}{|l|} 
Lymphoma \\
(Hodgkin's and \\
non Hodgkin's \\
disease)
\end{tabular} & & & Red meat & Italy (Northern) & $\begin{array}{l}\text { Tavani et al. } \\
2000\end{array}$ \\
\hline \begin{tabular}{|l|} 
Lymphoma \\
(non Hodgkin's)
\end{tabular} & $\begin{array}{l}\text { Trans-unsaturated fat (2.4); beef, pork, } \\
\text { or lamb (2.2) }\end{array}$ & & Broiled or barbecued red meat & $\begin{array}{l}\text { USA } \\
\text { (Massachusetts) }\end{array}$ & $\begin{array}{c}\text { Zhang et al. } \\
1999\end{array}$ \\
\hline Myeloma & & & Red meat & Italy (Northern) & Tavani et al. \\
\hline
\end{tabular}




\begin{tabular}{|c|c|c|c|c|c|}
\hline & & & & & 2000 \\
\hline \multirow[t]{3}{*}{$\begin{array}{l}\text { Oral } \\
\text { cavity/pharynx }\end{array}$} & & & Red meat & |taly (Northern) & $\begin{array}{l}\text { Tavani et al. } \\
2000\end{array}$ \\
\hline & ) $>$ & & Fried foods (1.11) & Italy, Switzerland & $\begin{array}{c}\text { Galeone et al. } \\
2005\end{array}$ \\
\hline & $\begin{array}{l}\text { Pork or processed meat (3.2), eggs } \\
(2.3) \text {, red meat }(2.1)\end{array}$ & Vegetables, fruit, milk, fish & & $\begin{array}{l}\text { Switzerland } \\
\text { (Canton of Vaud) }\end{array}$ & Levi et al .1998 \\
\hline \multirow[t]{2}{*}{ Ovary } & Red meat (1.53) & Vegetables, fish & & Italy & $\begin{array}{c}\text { Bosetti et al. } \\
2001\end{array}$ \\
\hline & Red meat (1.3) & & 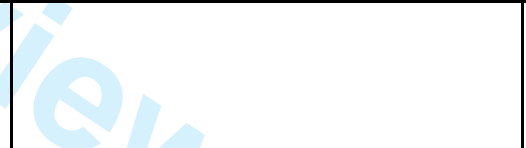 & Italy (Northern) & $\begin{array}{l}\text { Tavani et al. } \\
2000\end{array}$ \\
\hline \multirow[t]{2}{*}{ Pancreas } & $\begin{array}{l}\text { Deep-fried, grilled, cured, or smoked } \\
\text { foods }\end{array}$ & & $\begin{array}{l}\text { Preserved animal foods, fresh red meat, } \\
\text { organ meat, poultry }\end{array}$ & China (Shanghai) & Ji et al. 1995 \\
\hline & Red meat (1.6) & & & Italy (Northern) & $\begin{array}{l}\text { Tavani et al. } \\
2000\end{array}$ \\
\hline Prostate & & & Red meat & |taly (Northern) & $\begin{array}{l}\text { Tavani et al. } \\
2000\end{array}$ \\
\hline
\end{tabular}




\begin{tabular}{|c|c|c|c|c|c|}
\hline & $\begin{array}{l}\text { Red meat (2.0), total energy (1.9), total } \\
\text { fat and desserts (1.8) }\end{array}$ & $\begin{array}{l}\text { Vegetables and fruit (0.5), vitamin } E \\
(0.6) \text {, vitamin } C(0.4)\end{array}$ & & Uruguay & $\begin{array}{c}\text { Deneo Pellegrini } \\
\text { et al. } 1999\end{array}$ \\
\hline \multirow[t]{3}{*}{ Rectum } & Red meat (1.7) & & & |taly (Northern) & $\begin{array}{l}\text { Tavani et al. } \\
2000\end{array}$ \\
\hline & $\begin{array}{l}\text { High intake ( } \geq 94 \mathrm{~g} \text { ) of red meat } \\
\text { (women, prospective study: } 1.28 \text { ) }\end{array}$ & Poultry & Fish & Sweden & $\begin{array}{l}\text { Larsson et al. } \\
2005\end{array}$ \\
\hline & Red meat (1.71) & $(x)$ & & USA & Chao et al. 2005 \\
\hline Thyroid & & 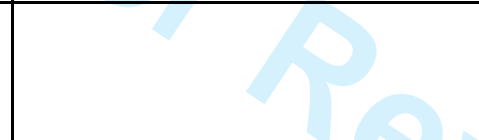 & Red meat & |taly (Northern) & $\begin{array}{l}\text { Tavani et al. } \\
2000\end{array}$ \\
\hline
\end{tabular}


Table IV. Estimated mean intakes of HAAs.

\begin{tabular}{|c|c|c|c|}
\hline Geographic location & "ng/person/day & ng/kg body mass/day & Ref. \\
\hline Japan & $\begin{array}{l}5-300(\mathrm{PhIP}) \\
300-3900(\mathrm{MelQx})\end{array}$ & & Wakabayashi et al. 1997 \\
\hline \multirow[t]{3}{*}{ Sweden } & $\begin{aligned} 160 & \text { (PhIP: 72) } \\
& \text { (MelQx: 72) } \\
& \text { (DiMelQx: 16) }\end{aligned}$ & 2.3 & Augustsson et al. 1997 \\
\hline & 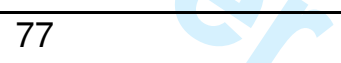 & & Augustsson et al. 1999 \\
\hline & 8.53 & $\bar{P}$ & Olsson et al. 2005 \\
\hline Switzerland & 330 & 5 & Zimmerli et al. 2001 \\
\hline \multirow[t]{2}{*}{ USA (2001) } & & $\begin{aligned} 1.4-2.1 & \text { (PhIP: } 1.1-1.6) \\
& \text { (MelQx: 0.29-0.47) } \\
& \text { (DiMelQx: } 0.021-0.031 \text { ) }\end{aligned}$ & Sinha et al. 2001 \\
\hline & 455 & 9 & Bogen and Keating 2001 \\
\hline \multirow[t]{2}{*}{ USA (Missouri) (1998) } & $70 \mathrm{~g}$ red meat/day & & Sinha et al. 1998 \\
\hline & $\begin{array}{l}\text { (PhIP: 158.3) } \\
\text { (MelQx: 52.1) } \\
\text { (DiMelQx: 3.5) }\end{array}$ & & Sinha et al. 2000 \\
\hline
\end{tabular}

